\title{
Annual cycle of volatile organic compound exchange between a boreal pine forest and the atmosphere
}

\author{
P. Rantala ${ }^{1}$, J. Aalto ${ }^{2}$, R. Taipale ${ }^{1}$, T. M. Ruuskanen ${ }^{1,3}$, and J. Rinne ${ }^{1,4,5}$ \\ ${ }^{1}$ Division of Atmospheric Sciences, Department of Physics, University of Helsinki, Helsinki, Finland \\ ${ }^{2}$ Department of Forest Sciences, University of Helsinki, Helsinki, Finland \\ ${ }^{3}$ Palmenia Centre for Continuing Education, University of Helsinki, Helsinki, Finland \\ ${ }^{4}$ Department of Geoscience and Geography, University of Helsinki, Helsinki, Finland \\ ${ }^{5}$ Finnish Meteorological Institute, Helsinki, Finland
}

Correspondence to: P. Rantala (pekka.a.rantala@helsinki.fi)

Received: 3 June 2015 - Published in Biogeosciences Discuss.: 26 June 2015

Accepted: 25 September 2015 - Published: 9 October 2015

\begin{abstract}
Long-term flux measurements of volatile organic compounds (VOC) over boreal forests are rare, although the forests are known to emit considerable amounts of VOCs into the atmosphere. Thus, we measured fluxes of several VOCs and oxygenated VOCs over a Scots-pine-dominated boreal forest semi-continuously between May 2010 and December 2013. The VOC profiles were obtained with a proton transfer reaction mass spectrometry, and the fluxes were calculated using vertical concentration profiles and the surface layer profile method connected to the Monin-Obukhov similarity theory. In total fluxes that differed significantly from zero on a monthly basis were observed for 13 out of 27 measured masses. Monoterpenes had the highest net emission in all seasons and statistically significant positive fluxes were detected from March until October. Other important compounds emitted were methanol, ethanol+formic acid, acetone and isoprene+methylbutenol. Oxygenated VOCs showed also deposition fluxes that were statistically different from zero. Isoprene+methylbutenol and monoterpene fluxes followed well the traditional isoprene algorithm and the hybrid algorithm, respectively. Emission potentials of monoterpenes were largest in late spring and autumn which was possibly driven by growth processes and decaying of soil litter, respectively. Conversely, largest emission potentials of isoprene+methylbutenol were found in July. Thus, we concluded that most of the emissions of $m / z 69$ at the site consisted of isoprene that originated from broadleaved trees.
\end{abstract}

Methanol had deposition fluxes especially before sunrise. This can be connected to water films on surfaces. Based on this assumption, we were able to build an empirical algorithm for bi-directional methanol exchange that described both emission term and deposition term. Methanol emissions were highest in May and June and deposition level increased towards autumn, probably as a result of increasing relative humidity levels leading to predominance of deposition.

\section{Introduction}

Knowledge on biogenic emissions of volatile organic compounds (VOCs) has been continuously increased as a result of a development of modelling methods and extended measurement network community (Guenther et al., 1995, 2006, 2012; Sindelarova et al., 2014). VOCs, such as monoterpenes and isoprene, make a major contribution to the atmospheric chemistry, including tropospheric ozone formation, control of atmospheric radical levels, and aerosol particle formation and growth. Therefore, these compounds affect both local and regional air quality and the global climate (Atkinson and Arey, 2003; Kulmala et al., 2004; Spracklen et al., 2008; Kazil et al., 2010).

In addition to terpenoids, vegetation also emits copious amounts of oxygenated volatile organic compounds (OVOCs). Their contribution to the total biogenic VOC bud- 
Table 1. The compound names and the formulas listed below in third and fourth column, respectively, are educated estimates for the measured masses (see e.g. de Gouw and Warneke, 2007). However, other compounds also might have a contribution at the measured masses (e.g. $m / z 85$, see Park et al., 2013). The second column shows whether a sensitivity was determined directly from the calibration or not (derived from a transmission curve, i.e. calculated), and which compounds were used in the calibrations.

\begin{tabular}{|c|c|c|c|}
\hline$[m / z]$ & Calibration compound & Compound & Chemical formula \\
\hline 31 & calculated & formaldehyde & $\mathrm{CH}_{2} \mathrm{O}$ \\
\hline \multirow[t]{2}{*}{33} & calibrated until & & \\
\hline & $\begin{array}{l}\text { 13.7.2011 with methanol, } \\
\text { after that calculated }\end{array}$ & methanol & $\mathrm{CH}_{4} \mathrm{O}$ \\
\hline 42 & acetonitrile & acetonitrile, alkane products & $\mathrm{C}_{2} \mathrm{H}_{3} \mathrm{~N}$ \\
\hline 45 & acetaldehyde & acetaldehyde & $\mathrm{C}_{2} \mathrm{H}_{4} \mathrm{O}$ \\
\hline 47 & calculated & ethanol, formic acid & $\mathrm{C}_{2} \mathrm{H}_{6} \mathrm{O}, \mathrm{CH}_{2} \mathrm{O}_{2}$ \\
\hline 59 & acetone & acetone & $\mathrm{C}_{3} \mathrm{H}_{6} \mathrm{O}$ \\
\hline 61 & calculated & acetic acid & $\mathrm{C}_{2} \mathrm{H}_{4} \mathrm{O}_{2}$ \\
\hline \multirow[t]{2}{*}{69} & isoprene & isoprene, & \\
\hline & & methylbutenol fragment & $\mathrm{C}_{5} \mathrm{H}_{8}$ \\
\hline 71 & MVK & $\begin{array}{l}\text { methacrolein, } \\
\text { methyl vinyl ketone }\end{array}$ & $\mathrm{C}_{4} \mathrm{H}_{6} \mathrm{O}$ \\
\hline 73 & MEK & methyl ethyl ketone & $\mathrm{C}_{4} \mathrm{H}_{8} \mathrm{O}$ \\
\hline 79 & benzene & benzene & $\mathrm{C}_{6} \mathrm{H}_{6}$ \\
\hline 81 & $\alpha$-pinene & monoterpene fragments & \\
\hline 83 & calculated & $\begin{array}{l}\text { methylfuran, } \\
\text { fragments of C6-products }\end{array}$ & $\mathrm{C}_{5} \mathrm{H}_{6} \mathrm{O}$ \\
\hline 85 & calculated & hexanol fragments & \\
\hline 87 & calculated & methylbutenol & $\mathrm{C}_{5} \mathrm{H}_{10} \mathrm{O}$ \\
\hline 93 & toluene & toluene, $p$-cymene fragment & $\mathrm{C}_{7} \mathrm{H}_{8}$ \\
\hline 99 & calculated & hexenal & $\mathrm{C}_{6} \mathrm{H}_{10} \mathrm{O}$ \\
\hline 101 & hexanal & hexanal & $\mathrm{C}_{6} \mathrm{H}_{12} \mathrm{O}$ \\
\hline 103 & calculated & hexanol & $\mathrm{C}_{6} \mathrm{H}_{14} \mathrm{O}$ \\
\hline 113 & calculated & unknown & \\
\hline 137 & $\alpha$-pinene & monoterpenes & $\mathrm{C}_{10} \mathrm{H}_{16}$ \\
\hline 141 & calculated & unknown & \\
\hline \multirow[t]{2}{*}{153} & calculated & $\begin{array}{l}\text { methyl salicylate, } \\
\text { oxidation products }\end{array}$ & $\mathrm{C}_{8} \mathrm{H}_{8} \mathrm{O}_{3}$ \\
\hline & & of monoterpenes & $\mathrm{C}_{10} \mathrm{H}_{16} \mathrm{O}$ \\
\hline 155 & calculated & cineol, linalool & $\mathrm{C}_{10} \mathrm{H}_{18} \mathrm{O}$ \\
\hline \multirow[t]{2}{*}{169} & calculated & oxidation products & \\
\hline & & of monoterpenes & $\mathrm{C}_{10} \mathrm{H}_{16} \mathrm{O}_{2}$ \\
\hline 205 & calculated & sesquiterpenes & $\mathrm{C}_{15} \mathrm{H}_{24}$ \\
\hline 263 & calculated & homosalate & $\mathrm{C}_{16} \mathrm{H}_{22} \mathrm{O}_{3}$ \\
\hline
\end{tabular}

get has been estimated to be ca. $10-20 \%$ in carbon basis (Guenther et al., 2012; Sindelarova et al., 2014). Due to their lower reactivity, OVOCs have only a minor role in the boundary layer chemistry but they can be transported to the upper troposphere where, for example, methanol can possibly have a major effect on oxidant formation (Tie et al., 2003; Jacob et al., 2005). Methanol emissions have been widely studied in recent years (e.g. Guenther et al., 2012 and references therein). However, it has been recently observed that methanol also has significant deposition at some ecosystems. This deposition could be related to the night-time dew on surfaces (Holzinger et al., 2001; Seco et al., 2007; Wohlfahrt et al., 2015) but removal mechanisms of methanol from the surfaces are still unknown (e.g. Laffineur et al., 2012). In global estimates, methanol deposition is usually determined with a deposition velocity that is tuned to fit concentration observations, leading possibly to uncertainties in methanol budget estimates (Wohlfahrt et al., 2015). Other OVOCs than methanol are even more poorly described in the global scale (Karl et al., 2010).

Generally, boreal forests are important emitters of monoterpenes for example, even though their contribution to global total VOC emission is surpassed by isoprene emission from tropical rainforest (e.g. Guenther et al., 2012). However, the negative temperature-monoterpene emissionaerosol feedback on the regional climate is estimated to be significant (up to $-0.6 \mathrm{Wm}^{-2} \mathrm{~K}^{-1}$, see Paasonen et al., 2013, and also Spracklen et al., 2008). 


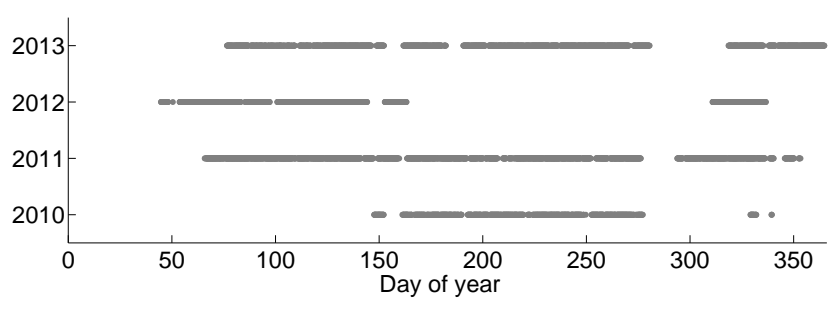

Figure 1. Grey dots show VOC flux data coverage for each year.

In order to describe the VOC exchange processes in models, continuous long-term ecosystem, or canopy, scale flux measurements play an important role (Guenther et al., 2006). They can be used to study the dependencies of these fluxes on environmental variables. Also, even when the process understanding has been obtained by, for example, laboratory experiments, the evaluation of model in ecosystem scale is a crucial step towards reliable global exchange estimates. Unfortunately, the ecosystem scale flux measurements are rare. As an example, even though branch scale monoterpene emissions from Scots pine are well-studied (Ruuskanen et al., 2005; Tarvainen et al., 2005; Hakola et al., 2006; Aalto et al., 2014, 2015), ecosystem scale emissions from Scots pine dominated forests have been mainly explored in short campaigns (Rinne et al., 2000b, a, 2007; Ghirardo et al., 2010). Longer time series have also consisted of measurements from May to September only (Räisänen et al., 2009; Taipale et al., 2011). This has had a direct effect on the capability of models to predict monoterpene concentrations (Smolander et al., 2014).

Thus, we have measured ecosystem scale fluxes of VOCs using the proton transfer reaction quadrupole mass spectrometer (PTR-MS, Lindinger et al., 1998) above a Scots-pinedominated forest in Hyytiälä at SMEAR II (Station for Measuring Forest Ecosystem-Atmosphere Relations) since 2010. In this study, we quantify the ecosystem scale VOC emissions and deposition at a boreal forest site throughout the seasonal cycle. The most important ecosystem scale VOCs emitted at the site are monoterpenes and methanol (Rinne et al., 2007), thus we concentrate on these compounds separately. Isoprene is also analysed more precisely because despite its importance on a global scale, ecosystem-scale emissions have remained unstudied in Scots-pine-dominated forests.

In the case of monoterpenes and isoprene, we will examine emissions with algorithms suggested by Guenther et al. (1993) and Ghirardo et al. (2010). Our purpose is to study how well the algorithms are able to predict ecosystem-scale fluxes, and how much there is seasonal variation in emission potentials. As the last aim, we examine the importance of the methanol deposition, and develop a simple empirical algorithm describing the bi-directional exchange needed to achieve more precise methanol flux budgets. This algorithm is evaluated against the measurements.

\section{Methods and measurements}

\subsection{Measurement site and VOC concentration calculations}

All measurements were conducted in Hyytiälä, Finland, at SMEAR II (Station for Measuring Forest EcosystemAtmosphere Relations, $61^{\circ} 51^{\prime} \mathrm{N}, 24^{\circ} 17^{\prime} \mathrm{E}, 180 \mathrm{~m}$ a.m.s.l., UTC+2). Hyytiälä is located in the boreal region and the dominant tree species in the flux footprint is Scots pine ( $\mathrm{Pi}$ nus sylvestris). In addition to Scots pine, there are some Norway spruce (Picea abies) and broadleaved trees such as European aspen (Populus tremula) and birch (Betula sp.). The forest is about 50-years old and the canopy height is currently ca. 18 m. Hari and Kulmala (2005), Haapanala et al. (2007) and Ilvesniemi et al. (2009) have given a detailed description about the station infrastructure and surrounding nature.

The proton transfer reaction quadrupole mass spectrometer (PTR-MS, manufactured by Ionicon Analytik GmbH, Innsbruck, Austria) was measuring 27 different masses (see Table 1) using a $2.0 \mathrm{~s}$ sampling time from six different measurement levels at a tower which was mounted on a protruding bedrock, ca. $2 \mathrm{~m}$ above the average forest floor. Two of the measurement levels $(4.2$ and $8.4 \mathrm{~m})$ were below the canopy and four of them $(16.8,33.6,50.4$ and $67.2 \mathrm{~m})$ above it. VOC fluxes were derived from the profile measurements with the surface layer profile method. The temperature was also measured at the VOC sampling levels with ventilated and shielded Pt-100 sensors. A 3-D acoustic anemometer (Gill Instruments Ltd., Solent 1012R2) was installed at the height of $23 \mathrm{~m}$ and it was used for determining turbulence parameters, including turbulent exchange coefficients. The photosynthetic photon flux density (PPFD, Sunshine sensor BF3, Delta-T Devices Ltd., Cambridge, UK) was measured at the height of $18 \mathrm{~m}$. The relative humidity (Rotronic AG, MP102H RH sensor) was measured at the height of $16 \mathrm{~m}$.

The PTR-MS was located inside the measurement cabin and samples were drawn down to the instrument using heated $14 \mathrm{~mm}$ i.d. PTFE tubing of equal length at all levels. The sample lines were $100 \mathrm{~m}$ long until the end of 2013 and $157 \mathrm{~m}$ from 2013 onwards. The change was due to the extension of the tower from 73 to $127 \mathrm{~m}$ length. A continuous airflow was maintained in the tubes $\left(43 \mathrm{~L} \mathrm{~min}^{-1}\right)$. From these lines a side flow of $0.1 \mathrm{~L} \mathrm{~min}^{-1}$ was transferred to PTR-MS via a $4 \mathrm{~m}$ PTFE tube with $1.6 \mathrm{~mm}$ i.d. During the measurements, the instrument was calibrated roughly every second week using two VOC standards (Apel-Riemer). The calibrations were performed with manually operated flow measurements until 7 July 2011 (Taipale et al., 2008). From that date onwards, the flow levels were obtained with a mass flow controller (Kajos et al., 2015). The volume mixing ratios were calculated using the procedure described in detail by Taipale et al. (2008). The primary ion signal $m / z 19$ (measured at $m / z 21$ ) had some variations over the years being approximately around $10-30 \times 10^{6} \mathrm{cps}$. SEM was always 
optimized before a calibration, and we used the same SEMmodel (MasCom MC-217) over all years.

The instrumental background was determined every third hour by measuring VOC free air, produced with a zero air generator (Parker ChromGas, model 3501). In addition, the estimated oxygen isotope $\mathrm{O}^{17} \mathrm{O}$ was subtracted from $m / z 33$ to avoid contamination of methanol signal. The isotope signal was estimated by multiplying the measured signal of $m / z 32$ by a constant $\mathrm{O}^{17} \mathrm{O} / \mathrm{O}_{2}$ ratio $(0.00076$, see Taipale et al., 2008). Samples for the zero air generator were taken outside of the measurement cabin close to the ground, and the stability of the zero air generator was followed continuously. We found that the generator had some problems at $m / z 93$ but this did not affect the flux calculations as the same zero air signal was subtracted from each concentration level.

\subsection{Flux calculation procedure}

The flux of a compound can be written as

$F=\overline{w^{\prime} c^{\prime}}=-c_{*} u_{*}$,

where $c_{*}=-\overline{w^{\prime} c^{\prime}} / u_{*}$ and $u_{*}=\left[\left(-\overline{u^{\prime} w^{\prime}}\right)^{2}+\left(-\overline{v^{\prime} w^{\prime}}\right)^{2}\right]^{1 / 4}$ is the friction velocity.

In this study, fluxes were quantified using the surface layer profile method. Detailed description of the flux calculation is given by Rantala et al. (2014), who use the term profile method of this variant of gradient method. Below we give only a brief outline of the method.

According to the Monin-Obukhov theory, a concentration $\bar{c}\left(z_{j}\right)$ can be calculated at any height $z_{j}$ in the surface layer using the formula

$\bar{c}\left(z_{j}\right)=\frac{c_{*}}{k} \chi\left(z_{j}\right)+\dot{X}$,

where

$$
\begin{aligned}
& \chi\left(z_{j}\right) \approx \ln \left(z_{\mathrm{M}}-d\right)-\Psi_{h}\left(\zeta_{M}\right)-\sum_{i=j}^{M-1} \frac{1}{\gamma\left(z_{i}, z_{i+1}\right)} \\
& {\left[\ln \left(\frac{z_{i+1}-d}{z_{i}-d}\right)-\Psi_{h}\left(\zeta_{i+1}\right)+\Psi_{h}\left(\zeta_{i}\right)\right]}
\end{aligned}
$$

and

$\dot{X}=\bar{c}\left(z_{0}\right)-\frac{c_{*}}{k}\left[\ln \left(z_{0}\right)-\Psi_{h}\left(z_{0} / L\right)\right]$.

Here, $k=0.4$ is the von Kármán constant (e.g. Kaimal and Finnigan, 1994), $\Psi_{h}(\zeta)$ is the integral form of the dimensionless universal stability function for heat, $z_{0}$ is the roughness length, and $\zeta=(z-d) / L$ is the dimensionless stability parameter where $L$ is the Obukhov length (Obukhov, 1971) and $d$ the zero displacement height. $L$ has been derived using dimensional analysis and it has the following form

$L=-\frac{u_{*}^{3} \bar{\theta}_{v}}{k g\left(\overline{w^{\prime} \theta_{v}^{\prime}}\right)_{s}}$ where $\bar{\theta}_{v}$ is the potential virtual temperature, $g$ the acceleration caused by gravity $\left(g \approx 9.81 \mathrm{~m} \mathrm{~s}^{-2}\right)$ and $\left(\overline{w^{\prime} \theta_{v}^{\prime}}\right)_{s}$ the turbulent heat transfer above the surface (in our case at $23 \mathrm{~m}$ ). $z_{0}$ is the surface roughness length, $z_{\mathrm{M}}$ the highest measurement level, and variables $x_{i}^{i+1}$ refer to the average values between heights $z_{i}$ and $z_{i+1}$. Using the equations above, the surface layer parameter $c_{*}$, and the flux, can be derived using the least square estimate (a linear fit).

For the flux calculation procedure, we selected $d=13 \mathrm{~m}$ and $\gamma=1.5$ between the two lowest levels (Rantala et al., 2014). Between other measurement levels, the roughness sublayer correction factor $\gamma$ was assumed to be 1, i.e. no corrections were applied. Our lowest and highest measurement levels were $z_{1}=16.8 \mathrm{~m}$ and $z_{\mathrm{M}}=67.2 \mathrm{~m}$, respectively. The concentrations, $\bar{c}\left(z_{j}\right)$, were computed as 45 min averages. From 2010 until the end of 2012, the averages from each level consisted of eight data points. From 2013 onwards, two new measurement heights (101 and $125 \mathrm{~m})$ were included in the cycle which reduced the amount of data points (per $45 \mathrm{~min}$ ) from eight to three at $50.4 \mathrm{~m}$.

Rantala et al. (2014) compared the profile method against the disjunct eddy covariance method. Based on those results, we decided to use the profile method for long-term measurements at the site as the DEC-method was often found to have problems in determining low VOC fluxes. For example, the lag-time determination was turned out to be difficult in conditions where values are usually close to flux detection limit. Moreover, the high-frequency losses are currently unknown for many VOCs as the response time of the PTR-MS has been studied for water vapour only (Rantala et al., 2014). On the other hand, the profile method has also several systematic error sources because it is an undirect method to measure fluxes, and is based on the parameterization of the surface layer turbulence.

\subsection{Flux filtering criteria, a gap-filling and other data processing tools}

Periods when the anemometer or the PTR-MS was working improperly, were removed from the time series (Figs. 1 and 2). The fluxes during which $\zeta<-2, \zeta>1$ or $u_{*}<$ $0.2 \mathrm{~m} \mathrm{~s}^{-1}$ were also rejected from further analysis. Finally, we disregarded $2.5 \%$ of the lowest and highest values from every month as outliers.

The filtering criteria applied were strongly turbulencedependent, which implies that night-time values had higher probability to be rejected. Therefore, monthly means, later introduced, were derived from gap-filled fluxes. In the gapfilling procedure, the missing flux values were replaced by a corresponding value from median diurnal cycle, calculated from the measurements made within a 16-day window around a missing value (Bamberger et al., 2014). However, there had to be at least one measured value on both sides of a missing value in the gap filling window, otherwise that missing value was not gap-filled. 

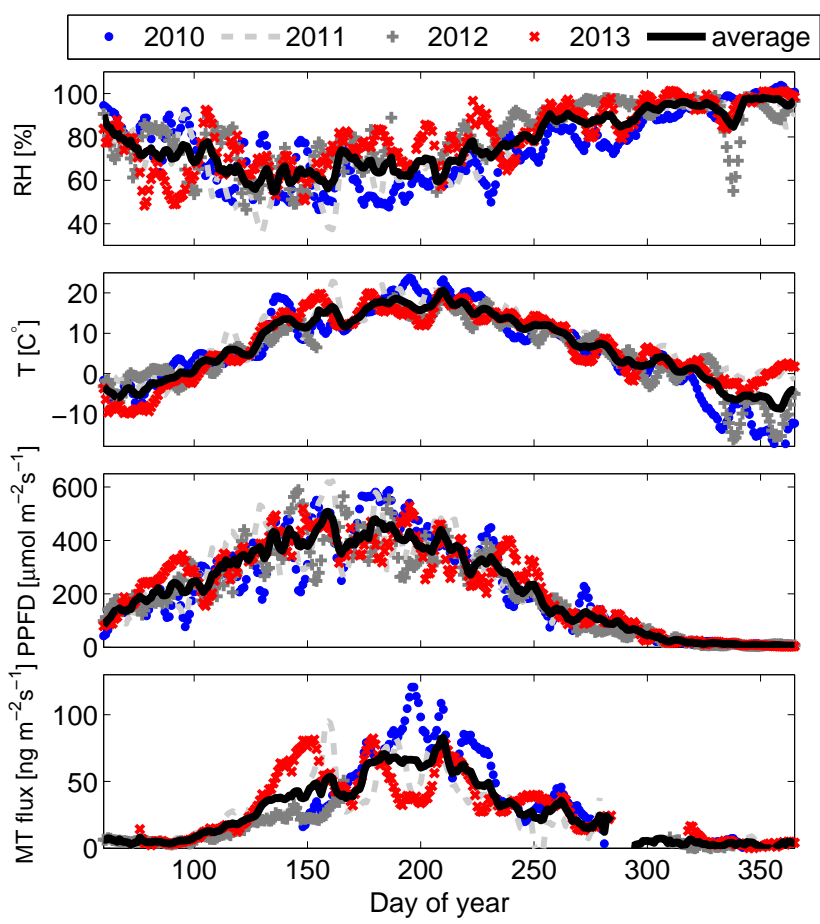

Figure 2. Five-day running averages of relative humidity (RH), temperature ( $T$ ), PPFD, and gap-filled monoterpene flux (MT flux) for each year as a function of day of year (days 60-365). The thick black solid lines represent averages calculated from the 5-day running means.

In this study, we have often used a relative error, $\Delta R$, that is defined as

$\Delta R=\frac{\|\boldsymbol{h}-\boldsymbol{q}\|}{\|\boldsymbol{h}\|}$,

where $\boldsymbol{h}$ corresponds to measured flux values and $\boldsymbol{q}$ to values given by an algorithm. Pearson's correlation coefficient, $r$, was used widely through the study as well, and it is hereafter referred as correlation.

Algorithm optimization is applied many times, and all fits were based on, if not stated otherwise, least squares minimization and a trust-region-reflective method that is provided as an option in MATLAB (function fit).

\subsection{Emission algorithms of isoprene and monoterpenes}

The well-known algorithm for isoprene emissions $\left(E_{\text {iso }}\right)$ is written as

$E_{\mathrm{iso}}=E_{\mathrm{synth}}=E_{0, \text { synth }} C_{T} C_{L}$,

where $E_{0 \text {,synth }}, C_{T}$ and $C_{L}$ are same as in the traditional isoprene algorithm (Guenther et al., 1991, 1993). The shape of this algorithm is based on the light response curve of electron transport activity and the temperature dependence of the protein activity. Similar behaviour for methylbutenol (MBO) emissions from Ponderosa pine has been suggested by for example Gray et al. (2005).

The algorithm we used for monoterpene emissions is the hybrid algorithm

$$
\begin{aligned}
& E_{\mathrm{mt}}=E_{\mathrm{synth}}+E_{\mathrm{pool}} \\
& =E_{0, \text { hybrid }}\left[f_{\mathrm{synth}} C_{T} C_{L}+\left(1-f_{\mathrm{synth}}\right) \Gamma\right],
\end{aligned}
$$

where $f_{\text {synth }} \in\left[\begin{array}{ll}0 & 1\end{array}\right]$ is the ratio $E_{0, \text { synth }} / E_{0, \text { hybrid }}$ (Ghirardo et al., 2010; Taipale et al., 2011). $E_{\text {pool }}$ is the traditional monoterpene algorithm by Guenther et al. (1991) and Guenther et al. (1993) and $\Gamma=\mathrm{e}^{\beta\left(T-T_{0}\right)}$ the temperature activity factor, where $\beta=0.09 \mathrm{~K}^{-1}$ and $T_{0}=303.15 \mathrm{~K}$. The hybrid algorithm is based on the observation that part of the monoterpene emission even from coniferous trees originates directly from synthesis. Therefore, it can be calculated using an algorithm similar to the isoprene emission algorithm while the rest originates as evaporation from large storage pools (Ghirardo et al., 2010). The latter can be calculated using the exponentially temperature-dependent algorithm, as the temperature dependence of the monoterpene saturation vapour pressure is approximately exponential (Guenther et al., 1991, 1993). The formula,

$E_{\mathrm{pool}}=E_{0, \mathrm{pool}} \Gamma$,

is hereafter referred to as the pool algorithm.

\subsection{Net exchange algorithm of methanol}

The total exchange of methanol consists of both emission term, $E_{\text {meth }}$, and deposition term, $D_{\text {meth }}$. Therefore, an algorithm for the methanol flux, $F_{\text {meth }}$, has the form of

$F_{\text {meth }}=E_{\text {meth }}-D_{\text {meth }}$.

According to observations, biogenic methanol production is mainly temperature-dependent, with photosynthesis having no direct role (Oikawa et al., 2011). Instead of that, the emissions are potentially controlled by stomatal opening, as methanol has high water solubility, i.e. low Henry's constant (e.g. Niinemets and Reichstein, 2003; Filella et al., 2009). Therefore, we assumed that part of the emissions could be represented by the traditional temperature activity factor $\Gamma$ multiplied by a light-dependent scaling factor of stomatal conductance. In addition, methanol is also produced by nonstomatal sources, such as decaying plant matter (Schade and Custer, 2004; Harley et al., 2007; Seco et al., 2007). Moreover, Aalto et al. (2014) observed with chamber studies that at least part of the methanol emissions is independent of light during springtime. Hence, we estimated that the total methanol emission, $E_{\text {meth }}$, is determined as

$E_{\text {meth }}=E_{0, \text { meth }}\left[f_{\text {stomata }} G_{\text {light }}+\left(1-f_{\text {stomata }}\right)\right] \Gamma$,

where $E_{0, \text { meth }}$ and $f_{\text {stomata }} \in\left[\begin{array}{ll}0 & 1\end{array}\right]$ are an emission potential and a fraction of stomatal controlled emissions, respectively. 
The light-dependent scaling factor of stomatal conductance, $G_{\text {light }}$, was estimated as

$G_{\text {light }} \approx 1-\mathrm{e}^{-\alpha \cdot \mathrm{PPFD}}$,

where $\alpha=0.005 \mu \mathrm{mol}^{-1} \mathrm{~m}^{2} \mathrm{~s}$ is the same as used by Altimir et al. (2004) for pine needles. The stomatal conductance is also dependent on, for example, the temperature and vapour pressure deficit but their effect is much weaker than the effect of light at the site (Altimir et al., 2004). For the temperature activity factor, we used a parameter $\beta=0.09$. In principle, $\beta$ should be determined from measurements but we wanted to have as few experimental parameters as possible. Therefore, we used the same value as for monoterpenes.

We assumed that methanol is deposited on wet surfaces, such as on dew, in a way that the methanol concentration at the absorbing surface is zero. Thus, a deposition term, $D_{\text {meth }}$, was estimated to be

$D_{\text {meth }}=f(\mathrm{RH}) V_{\mathrm{d}} \cdot \rho_{\text {methanol }}$,

where $\rho_{\text {methanol }}$ is a mass mixing ratio measured at $z=33.6$ $\mathrm{m}$ and $V_{\mathrm{d}}$ a deposition velocity. The function $f(\mathrm{RH})$ defines a filter of relative humidity (RH) in a such way that

$f(\mathrm{RH})= \begin{cases}0, & \text { if } \mathrm{RH} \leq \mathrm{RH}_{0} \\ 1, & \text { if } \mathrm{RH}>\mathrm{RH}_{0}\end{cases}$

where $\mathrm{RH}_{0}$ was determined from the measurements. The deposition velocity $V_{\mathrm{d}}$ was determined by a resistance analogy:

$V_{\mathrm{d}}=\frac{1}{R_{\mathrm{a}}+R_{\mathrm{b}}+R_{\mathrm{w}}}$,

where $R_{\mathrm{a}}$ is the aerodynamic resistance, $R_{\mathrm{b}}$ the laminar boundary-layer resistance, and $R_{\mathrm{W}}$ a surface resistance. The aerodynamic resistance is written as:

$R_{\mathrm{a}}=\frac{1}{\gamma\left(z_{1}, z_{2}\right) k u_{*}}\left[\ln \left(\frac{z-d}{z_{0}}\right)-\Psi_{h}(\zeta)\right]$,

where the correction factor $\gamma\left(z_{1}, z_{2}\right)=1.5$ as with the flux calculations. $R_{\mathrm{b}}$ was determined by a commonly used formula (Wesely and Hicks, 1977)

$R_{\mathrm{b}}=2\left(u_{*} k\right)^{-1}\left(\frac{\kappa}{\eta}\right)^{2 / 3}$

where $\eta$ is a diffusivity of methanol and $\kappa$ a thermal diffusivity of air. The factor $R_{\mathrm{W}}$ was assumed to be constant and it was determined from the measurements. In reality, $R_{\mathrm{w}}$ might be also consisting of stomatal uptake due to oxidation of methanol into formaldehyde on leaves (Gout et al., 2000). Consequently, the assumption of a constant value is a very rough estimate. However, in order to simplify the algorithm as much as possible, the parameterized deposition velocity consisted only of the factors $R_{\mathrm{a}}, R_{\mathrm{b}}$ and a constant
$R_{\mathrm{W}}$. We used the constant values of $1 \mathrm{~m}$ and $13 \times 10^{-6} \mathrm{~m}^{2} \mathrm{~s}^{-1}$ for the surface roughness length $\left(z_{0}\right)$ and for the diffusivity of methanol $(\eta)$, respectively. The diffusivity of methanol was approximated at $273.15 \mathrm{~K}$ using Chapman-Enskog theory (e.g. Cussler, 1997). Generally, the diffusion coefficient, and thus the deposition velocity, would be larger at higher temperatures. However, using the constant value causes only a minor error. We assumed also a constant value for the thermal diffusivity of air $\left(\kappa=19 \times 10^{-6} \mathrm{~m}^{2} \mathrm{~s}^{-1}\right)$.

\section{Results and discussion}

\subsection{Statistical significance of fluxes}

For the analysis of seasonal cycle the fluxes were divided into 12 monthly bins, each containing data from a specific month of all years. To study whether the measured fluxes from each month differed significantly from zero or not, numbers of positive and negative fluxes were counted. The null hypothesis was that there is no flux, thus the counts of positive and negative values are equal. Finally, it was determined from the binomial distribution with a confidence level of $99.9937 \%$ (" $4 \sigma$ ", Clopper-Pearson method) whether a fraction of positive and negative values could be generated by a random process (the null hypothesis), or if there was a real positive or negative flux, i.e. the null hypothesis was rejected. We made the test for both night- (2-8 a.m.) and daytime (11 a.m.-5 p.m.) fluxes separately. Measurements from January and February were excluded from the analysis due to the lack of data points. Measurements at higher mass-to-charge ratio $(m / z)$ than 137 were also left out from the analysis due to a very low sensitivity of the PTR-MS at those masses. In addition, identification of the heavier masses was proven to be extremely difficult.

Altogether, 13 masses (excluding monoterpene fragments at $m / z 81$ ) had statistically significant fluxes on a monthly scale (Table 2). One should note that the masses for which no significant flux was found $(m / z 71, m / z 79, m / z 85, m / z 99$, $m / z 101, m / z 103$, and $m / z 113$ ) may have fluxes. This result of the analysis only indicates that with the $4 \sigma$ criteria, the fluxes of these masses were non-significantly different from zero on a monthly scale.

Monoterpenes $(m / z$ 137) had the highest net emissions in every month analysed except in December and November, whereas methanol and acetone $(\mathrm{m} / z 33$ and $m / z 59)$ showed generally the strongest net deposition. Other important compounds emitted or deposited were acetaldehyde $(\mathrm{m} / \mathrm{z} 45)$, ethanol+formic acid $(m / z 47)$, acetic acid $(\mathrm{m} / z 61)$ and isoprene+methylbutenol $(\mathrm{m} / z$ 69; Table 2$)$.

Surprisingly, statistically significant formaldehyde fluxes were also observed. However, formaldehyde is poorly detected and quantified with the PTR-MS due to its low proton affinity. Thus, the observed fluxes may be related for example to the behaviour of water vapour (de Gouw and 
Table 2. The table includes daytime, night-time, and diurnal flux averages (arithmetic) for each month (years 2010-2013). The values are expressed with two significant numbers but with a maximum of one decimal. Significant $(4 \sigma)$ averages are marked with an asterisk $(*)$. A diurnal average was defined to be statistically significant if either a daytime value or the night-time value differed statistically from zero. The fluxes have unit of $\mathrm{ng} \mathrm{m}^{-2} \mathrm{~s}^{-1}$.

\begin{tabular}{|c|c|c|c|c|c|c|c|c|c|c|c|c|c|}
\hline Month & $m / z 31$ & $m / z 33$ & $m / z 42$ & $m / z 45$ & $m / z 47$ & $m / z 59$ & $m / z 61$ & $m / z 69$ & $m / z 73$ & $m / z 83$ & $m / z 87$ & $m / z 93$ & $m / z 137$ \\
\hline \multicolumn{14}{|l|}{ Mar } \\
\hline Night & -0.4 & 2.2 & 0.1 & 1.0 & 1.2 & 0.9 & 0.8 & 0.3 & 0.4 & 0.1 & -0.1 & 1.6 & $4.9^{*}$ \\
\hline Day & -0.3 & 3.3 & 0.1 & 1.7 & 4.1 & 2.7 & 1 & 0.5 & 0.1 & 0 & 0.3 & 1.9 & 5.4 \\
\hline All & -0.1 & 2.5 & 0.1 & 1.2 & 2.3 & 1.6 & 1 & 0.3 & 0.1 & 0 & 0.2 & 1.1 & $4.6^{*}$ \\
\hline \multicolumn{14}{|l|}{ Apr } \\
\hline Night & -0.2 & 1.3 & -0.1 & -0.2 & 3.8 & 1.3 & $2.2^{*}$ & 0.5 & -0.1 & 0 & 0.5 & $3.3^{*}$ & $10^{*}$ \\
\hline Day & 0.3 & 4.3 & -0.1 & 1.3 & $6.2^{*}$ & 3.7 & $4.3^{*}$ & 0.7 & 0.3 & 0.1 & 0.4 & $5.1^{*}$ & $16^{*}$ \\
\hline All & 0 & 2.3 & -0.1 & 0.4 & $4.3^{*}$ & 2.2 & $2.9^{*}$ & 0.5 & 0.1 & 0.1 & 0.4 & $3.9^{*}$ & $12^{*}$ \\
\hline \multicolumn{14}{|l|}{ May } \\
\hline Night & 0.1 & $7.6^{*}$ & $-0.1^{*}$ & $1.5^{*}$ & $7.2^{*}$ & $5.9^{*}$ & $5.2^{*}$ & $1.6^{*}$ & 0.5 & $0.3^{*}$ & $0.9^{*}$ & $5.5^{*}$ & $26^{*}$ \\
\hline Day & 0.6 & $20^{*}$ & -0.1 & $3.3^{*}$ & $17^{*}$ & $11^{*}$ & $11^{*}$ & $4.2^{*}$ & 1.3 & 0.3 & $2.2^{*}$ & $9.2^{*}$ & $56^{*}$ \\
\hline All & 0.3 & $12^{*}$ & $-0.1^{*}$ & $2.1^{*}$ & $9.8^{*}$ & $7.3^{*}$ & $6.7^{*}$ & $2.4^{*}$ & 0.7 & $0.3^{*}$ & $1.2^{*}$ & $6.5^{*}$ & $36^{*}$ \\
\hline \multicolumn{14}{|l|}{ Jun } \\
\hline Night & $-1.8^{*}$ & 4.4 & $-0.2^{*}$ & -0.9 & $6.2^{*}$ & $4.1^{*}$ & $7.4^{*}$ & $3.4^{*}$ & 0.9 & $0.3^{*}$ & $0.8^{*}$ & $4.9^{*}$ & $38^{*}$ \\
\hline Day & $-0.5^{*}$ & $27^{*}$ & -0.1 & 2.3 & $16^{*}$ & $14^{*}$ & $17^{*}$ & $9.5^{*}$ & $2.5^{*}$ & 0.7 & 2.7 & $8.3^{*}$ & $72^{*}$ \\
\hline All & $-1.0^{*}$ & $14^{*}$ & $-0.2^{*}$ & 1 & $9.5^{*}$ & $8.2^{*}$ & $10^{*}$ & $5.4^{*}$ & $1.5^{*}$ & $0.5^{*}$ & $1.4^{*}$ & $5.8^{*}$ & $50^{*}$ \\
\hline \multicolumn{14}{|l|}{ Jul } \\
\hline Night & $-1.2^{*}$ & 1.9 & -0.1 & 2.4 & 5.5 & $7^{*}$ & 1.9 & $5.7^{*}$ & $1.1^{*}$ & $0.5^{*}$ & $1.1^{*}$ & $3.4^{*}$ & $61^{*}$ \\
\hline Day & -0.6 & $30^{*}$ & -0.1 & $9.5^{*}$ & $16^{*}$ & $19^{*}$ & $11^{*}$ & $18^{*}$ & $4.4^{*}$ & $1^{*}$ & $3.4^{*}$ & $7^{*}$ & $94^{*}$ \\
\hline All & $-0.8^{*}$ & $14^{*}$ & -0.1 & $5^{*}$ & $8.4^{*}$ & $11^{*}$ & $5.6^{*}$ & $9.8^{*}$ & $2.3^{*}$ & $0.7^{*}$ & $1.8^{*}$ & $4.3^{*}$ & $69^{*}$ \\
\hline \multicolumn{14}{|l|}{ Aug } \\
\hline Night & -0.8 & $-5.4^{*}$ & $-0.5^{*}$ & 0.5 & 3.7 & 0.8 & 3.4 & $2^{*}$ & 0.6 & $0.2^{*}$ & -0.1 & $2.5^{*}$ & $39^{*}$ \\
\hline Day & -0.8 & $18^{*}$ & 0.2 & $5.5^{*}$ & $14^{*}$ & $12^{*}$ & $9.6^{*}$ & $7.9^{*}$ & $2.6^{*}$ & 0.5 & 2.1 & $6.1^{*}$ & $63^{*}$ \\
\hline All & -0.7 & $4.7^{*}$ & $-0.1^{*}$ & $2.5^{*}$ & $7.3^{*}$ & $5.4^{*}$ & $5.2^{*}$ & $3.8^{*}$ & $1.3^{*}$ & $0.3^{*}$ & 0.8 & $3.5^{*}$ & $44^{*}$ \\
\hline \multicolumn{14}{|l|}{ Sep } \\
\hline Night & -0.5 & $-7.9^{*}$ & $-0.5^{*}$ & -1.3 & 0.2 & $-4.6^{*}$ & 0.4 & 0.1 & -0.3 & -0.4 & -0.3 & 0.4 & $23^{*}$ \\
\hline Day & -0.9 & 3.7 & $-0.4^{*}$ & 1.2 & 4.8 & -0.4 & 3.2 & 1.3 & 0.7 & 0.2 & 0.5 & 1.9 & $35^{*}$ \\
\hline All & -0.6 & $-2.9^{*}$ & $-0.4^{*}$ & -0.1 & 2 & $-2.7^{*}$ & 1.3 & 0.5 & 0.1 & -0.1 & 0 & 0.9 & $25^{*}$ \\
\hline \multicolumn{14}{|l|}{ Oct } \\
\hline Night & -0.1 & $-5^{*}$ & -0.4 & -1.5 & -0.3 & -3 & 1.3 & 0.8 & -0.5 & -0.4 & 1.1 & 0 & $15^{*}$ \\
\hline Day & -1.1 & -3.4 & 0 & 0.9 & 0 & 0 & 2.7 & -0.3 & 0.6 & 0.4 & 1.1 & 2.7 & $15^{*}$ \\
\hline All & 0 & $-4.3^{*}$ & -0.2 & -0.5 & 0.1 & -1.7 & 1.4 & 0.3 & 0.1 & 0 & 0.9 & 1.3 & $13^{*}$ \\
\hline \multicolumn{14}{|l|}{ Nov } \\
\hline Night & -1.3 & -2.5 & -0.1 & -1 & 1.9 & $-3^{*}$ & 0.5 & 0.6 & -0.2 & 0.1 & -0.3 & 4.1 & 4.2 \\
\hline Day & -0.1 & -2.6 & -0.3 & -1.3 & 2.2 & $-2.8^{*}$ & 0.6 & -0.4 & -0.3 & -0.1 & 0.1 & 4.7 & 2.7 \\
\hline All & -0.4 & -3 & -0.2 & -1.2 & 2 & $-2.8^{*}$ & 0.5 & 0 & -0.1 & -0.1 & -0.2 & 4 & 2.9 \\
\hline \multicolumn{14}{|l|}{ Dec } \\
\hline Night & -2.1 & -5.2 & -0.2 & -2 & 2.8 & -2.5 & 2.1 & -0.4 & -0.2 & 0.2 & 0.3 & 0.5 & 3 \\
\hline Day & -2.4 & -1.1 & -0.3 & -1.5 & 4.8 & -1.8 & 3.0 & -0.6 & -0.5 & -0.2 & 0.5 & 2.9 & 3.7 \\
\hline All & -1.5 & -3.7 & -0.2 & -1.8 & 3.2 & -2.2 & 2.8 & -0.2 & -0.1 & 0 & 0.3 & 1.5 & 3.2 \\
\hline
\end{tabular}


Warneke, 2007). We tried to minimize the interference of water vapour using a normalization method which takes into account changes in water cluster ions (Taipale et al., 2008).

There were also other controversial discoveries such as net emissions of $m / z 93$. A compound at $m / z 93$ is usually connected with toluene but it might be a fragmentation product of $p$-cymene as well (Ciccioli et al., 1999; Heiden et al., 1999; White et al., 2009; Ambrose et al., 2010; Park et al., 2013). We found a dependency between the $m / z 93$ fluxes and $E / N$ where $E$ is the electric field and $N$ the number density of the gas in the drift tube. This indicates that observed positive fluxes could originate at least partly from the monoterpene-related $p$-cymene (Tani et al., 2003).

An interesting result is weak but detectable acetonitrile deposition in June, August and September. Similar observations were done earlier by, for example, Sanhueza et al. (2004) who suggested that acetonitrile is deposited in the tropical savannah ecosystem. Their results imply a deposition velocity of ca. $0.1 \mathrm{~cm} \mathrm{~s}^{-1}$ for acetonitrile. Our deposition velocities were somewhat higher as the typical acetonitrile concentration was around $100 \mathrm{ng} \mathrm{m}^{-3}$, and the flux values around $-0.5 \mathrm{ng} \mathrm{m}^{-2} \mathrm{~s}^{-1}$. This corresponds to the deposition velocity of $0.5 \mathrm{~cm} \mathrm{~s}^{-1}$. According to Dunne et al. (2012), $m / z 42$ signal might be affected by alkanes. The $m / z 42$ concentration also had a correlation with $m / z 71$ $(r=0.57), m / z 85(r=0.47)$ and $m / z 99(r=0.38)$ concentrations (typical alkane fragments, see Erickson et al., 2014). Thus, also other compounds than acetonitrile might have a contribution to the measured signal of $m / z 42$. However, no correlations were seen between measured $m / z 42$ and alkane fluxes. Fluxes of $m / z 71, m / z 85$ and $m / z 99$ were actually even statistically insignificant (Table 2). Therefore, we concluded that acetonitrile had a major contribution to the observed deposition of $m / z 42$.

The measured fluxes do have significant uncertainties. Some of these are random in nature and will thus cancel out with data analysis of a sufficiently large data set. Some of the uncertainties are more systematic and may bias average flux values presented. The surface layer profile method itself may have a systematic error of about $10 \%$ (Rantala et al., 2014). In addition, monoterpene fluxes are underestimated up to a few percent by the chemical degradation (Spanke et al., 2001; Rinne et al., 2012; Rantala et al., 2014). Our calibration procedure may also contain systematic error sources. This concerns especially the indirect calibration if molecules are fragmented, such as in the case of methylbutenol at $m / z 87$ (Taipale et al., 2008). In addition to systematic errors, random flux uncertainties are also several hundreds of percent for many compounds (Rantala et al., 2014). On the other hand, when averaging over a sample size of ca. a hundred data points, a random uncertainty of the average is decreased to the scale of $10 \%$.

After the addition of a mass flow controller to the calibration system on 7 July 2011, the sensitivities of methanol were observed to be highly underestimated. The reason was
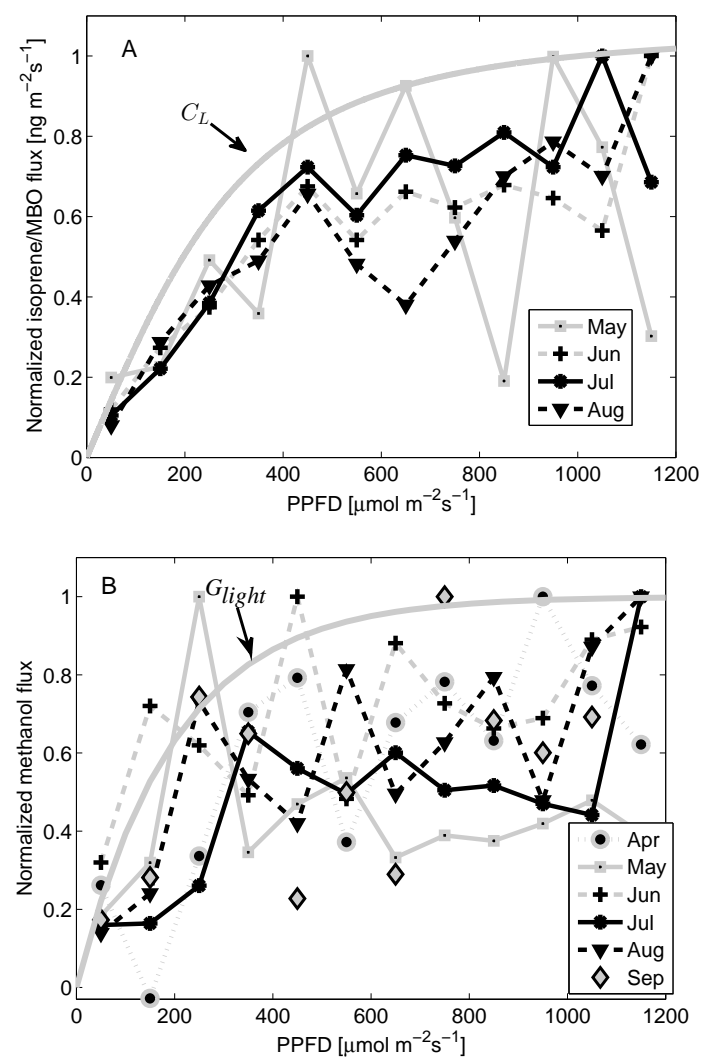

Figure 3. Temperature normalized isoprene $+\mathrm{MBO}$ (a) and methanol (b) fluxes (bin-medians) as a function of PPFD (MayAugust and April-September, respectively; years 2010-2013). The isoprene fluxes were normalized by multiplying the measured values by a factor of $C_{T}^{-1}$ (Eq. 7) whereas the methanol fluxes were multiplied by a factor of $\Gamma^{-1}$ (Eq. 11). In addition, values for each month were scaled to the range of $[0-1]$. Those periods when relative humidity was larger than $75 \%$ were rejected from the methanol analysis to avoid deposition.

unknown but the biased sensitivities were probably caused by an absorption of methanol on metal surfaces of the mass flow controller (Kajos et al., 2015). Therefore, methanol concentrations were derived from general transmission curves (indirect calibration) after that date (Table 2). The indirect calibration might potentially lead to large systematic errors. However, no rapid changes in the methanol concentrations were observed after 7 July 2011.

\subsection{Monoterpene and isoprene fluxes}

\subsubsection{Isoprene or MBO?}

Both isoprene and $\mathrm{MBO}$ are detected at $m / z 69$. The parent and primary $m / z$ of the MBO is 87 but a considerable part of the ions fragment producing $m / z 69$ inside a PTRMS (de Gouw and Warneke, 2007). The fragmentation ratio depends on the instrument setting but Karl et al. (2012) men- 
tion that typically only $25 \%$ of the ions is detected at $m / z 87$. As the identification of compound observed at $m / z 69$ is not unambiguous, we analysed the fluxes of this mass in more detail to determine if it is more likely to be isoprene or MBO. MBO is produced by conifers (Harley et al., 1998) whereas many broad-leaved trees are high isoprene emitters (Sharkey and Yeh, 2001; Rinne et al., 2009).

In order to quantify the emission potentials for isoprene+MBO, measured flux values were fitted against the isoprene algorithm (Eq. 7) for each month separately. We found a significant correlation between the measurements and the calculated emissions from May, June, July and August (Table 3). Here we defined that the measurements and the calculated values correlated significantly if the $p$ value $(p)$ of the correlation $(r)$ was smaller than 0.0027 (3ocriteria). In June, July, and August, the measured fluxes were also clearly light-dependent (Fig. 3). Shapes of the curves in Fig. 3 go near to zero when PPFD is zero and the normalized values have also their saturation point around $\mathrm{PPFD}=500 \mu \mathrm{mol} \mathrm{m}{ }^{-2} \mathrm{~s}^{-1}$ where $C_{L}$ is also already larger than 0.8 (Fig. 3). In May, the dependency between the measured fluxes and light was, however, unclear. However, the calculated values corresponded well with the measured ones as is seen in Fig. 4.

Previous emission studies with chamber method with gas chromatography have shown that Scots pines emit MBO much more than isoprene (Tarvainen et al., 2005; Hakola et al., 2006). However, emission potentials of MBO in those studies were only around 2-5\% of emission potentials of total monoterpenes whereas in this study, we found the ecosystem scale emission potentials of $m / z 69$ to be around 15$25 \%$ of emission potentials of monoterpenes. Thus, MBO emissions from Scots pines cannot fully explain $m / z 69$ flux. On the other hand, we may be able to explain the $m / z 69$ emission if we assume that isoprene emission from the mixture of spruce, aspen and willow within the footprint area make a considerable contribution in the ecosystem scale emission.

Hakola et al. (2006) observed that maximum MBO emission potential of Scots pine occurs around May and June, and Aalto et al. (2014) showed that the increased MBO emissions during early summer were related to new biomass growth. In the case of isoprene emissions from aspen, the maximum should come later in July (Fuentes et al., 1999). In this study, the maximum emission potential of $m / z 69$ was observed in July, indicating that most of the emissions of $m / z 69$ might actually consist of isoprene. Maximum net emissions of $m / z 87$ were also detected in July (Table 2) but the temperature and light normalized fluxes of $\mathrm{m} / z 87$ were largest in May as expected. Even though quantifying the ratio between the MBO and isoprene emissions based on PTR-MS measurements alone is somewhat speculative.

\subsubsection{Monoterpenes, their emission potentials and differences to branch scale studies}

Monoterpenes are emitted by Scots pine (Hakola et al., 2006), Birch (Hakola et al., 2001) and forest floor (Hellén et al., 2006; Aaltonen et al., 2011, 2013) at the site. According to Taipale et al., 2011, Scots pine is the most important monoterpene source in summer but its fraction of the total emission in spring and autumn have remained unstudied. Therefore, monoterpene fluxes from spring- and autumntime will be analysed more carefully in this chapter.

Unsurprisingly, a seasonal cycle of monoterpene fluxes correlated roughly with the temperature (Fig. 2). To examine a response of monoterpene fluxes to the temperature and light in more detail, the fluxes were fitted against the hybrid algorithm and the pool algorithm (Eqs. 8 and 9) for each month separately (Fig. 5). We found a correlation ( $p$ value was smaller than 0.0027) between the measurements and the hybrid algorithm from April to October (Table 4).

Significant monoterpene fluxes were also observed in March but no dependence with the temperature was found. This is most probably due to the low temperatures and its diurnal variation, letting the random variation in the flux data to dominate. In addition, Aalto et al. (2015) observed that freezing-thawing cycles may increase the monoterpene emission capacity of Scots pine shoots; in late autumn and early spring such cycles are frequent and potentially hide the relation between temperature and emissions at least partially. Nevertheless, monoterpene fluxes in March were in a reasonable range being lower than in April (Table 2, Fig. 6).

Correlations between measured fluxes and the hybrid emission algorithm were better than those between measured fluxes and the pool algorithm in every month analysed (Table 4). In addition, relative errors (Eq. 6) between the measured fluxes and the hybrid algorithm were also smaller than the relative errors between the measured fluxes and the pool algorithm. Thus, the hybrid algorithm worked better than the pool algorithm in every month. The result was expected as Taipale et al. (2011) showed that ecosystem scale monoterpene emission from Scots pine forest, measured by the disjunct eddy covariance method, has a light-dependent part. In addition, Ghirardo et al. (2010) have shown by stable isotope labelling that a major part of the monoterpene emissions from conifers originates directly from synthesis (de novo). In this study, the ratios $f_{\text {synth }}=E_{\text {synth }} / E_{\text {pool }}$ varied between 0.36 (July) and 0.79 (October) whereas Ghirardo et al. (2010) estimated that the fraction of the de novo emissions from Scots pine seedlings to be around $58 \%$, and Taipale et al. (2011) estimated the fraction to be around $40 \%$ for the Scots pine ecosystem. Generally, these estimates fit well with our results considering the relatively large uncertainties (Table 4)

In the case of the hybrid algorithm, the largest emission potentials were found in May and in October $(390 \pm 30$ and $400 \pm 150 \mathrm{ng} \mathrm{m}^{-2} \mathrm{~s}^{-1}$, respectively), although interan- 

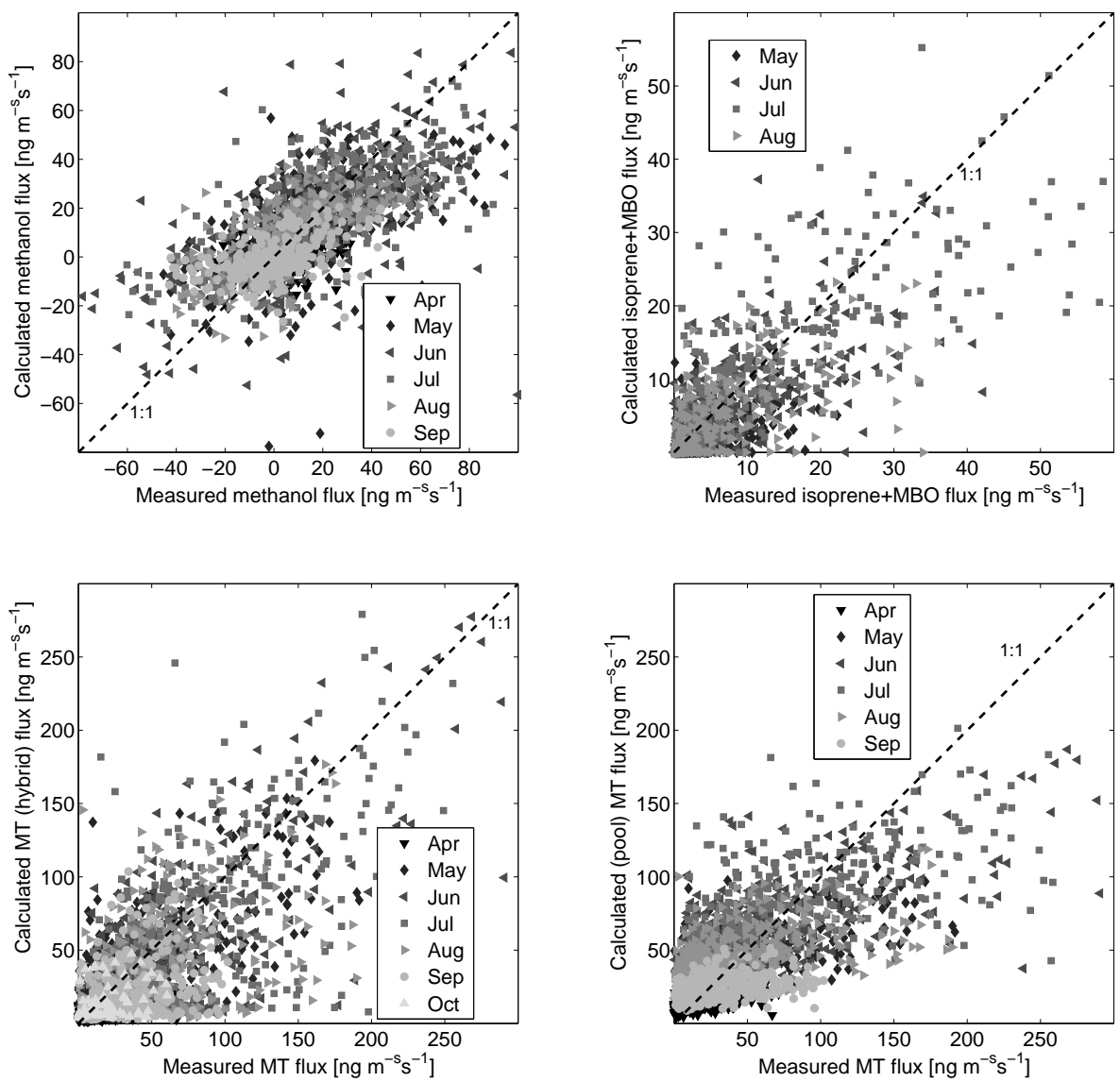

Figure 4. Calculated values versus measured methanol, isoprene and monoterpene fluxes for each month. Measured monoterpene fluxes have been compared against both hybrid and pool algorithm.

Table 3. The table presents isoprene+MBO emission potential of a synthesis algorithm, $E_{0, \text { synth }}$, including $95 \%$ confidence intervals (years 2010-2013). The table shows also correlations coefficients $(r)$, relative errors between the measurements and the calculated values $(\Delta R)$, and a ratio, $\overline{F_{\mathrm{a}}} / \bar{F}$, where $\overline{F_{\mathrm{a}}}$ is an average value given by the algorithm and $\bar{F}$ an average value of the measurements. If the $p$ value of a correlation was larger than 0.0027 , the result was disregarded as statistically insignificant, and those values are not shown in the table.

\begin{tabular}{lrrrr}
\hline Month & $\begin{array}{r}E_{0, \text { synth }} \\
{\left[\mathrm{ng} \mathrm{m}^{-2} \mathrm{~s}^{-1}\right]}\end{array}$ & $r$ & $\overline{F_{\mathrm{a}}} / \bar{F}$ & $\begin{array}{r}\Delta R \\
{[\%]}\end{array}$ \\
\hline May & $36 \pm 5$ & $0.42\left(n=503, p<10^{-4}\right)$ & 1.09 & 81 \\
Jun & $52 \pm 4$ & $0.67\left(n=361, p<10^{-4}\right)$ & 1.02 & 59 \\
Jul & $63 \pm 4$ & $0.77\left(n=397, p<10^{-4}\right)$ & 0.98 & 49 \\
Aug & $40 \pm 4$ & $0.61\left(n=402, p=1.7 \times 10^{-4}\right)$ & 1.05 & 68 \\
\hline
\end{tabular}

nual variation of the potentials was considerably large in May. The emission potentials of May varied from 210 (2012) to $470 \mathrm{ng} \mathrm{m}^{-2} \mathrm{~s}^{-1}$ (2013) whereas in July, the range was from 200 (2013) to $290 \mathrm{ng} \mathrm{m}^{-2} \mathrm{~s}^{-1}$ (2010). The high variability might be connected to the differences in the temperatures as the average temperatures were 12 and $8.5^{\circ} \mathrm{C}$ in May 2013 and in May 2012, respectively. Overall, the high springtime monoterpene emissions have been connected to new biomass growth, including the expansion of new cells, tissues and organs (Aalto et al., 2014), photosynthetic spring recovery (Aalto et al., 2015) and increased activity of soil and forest floor (Aaltonen et al., 2011, 2013). Considerable differences in emission potentials between early and late summer have been reported also earlier (Tarvainen et al., 2005; Hakola et al., 2006). For example, Tarvainen et al. (2005) found that the emission potential of monoterpenes was five times higher in early summer than in late summer. In that study, however, the parameter $\beta$ was ca. 0.18 in the early summer and only ca. 0.08 in the late summer which makes 


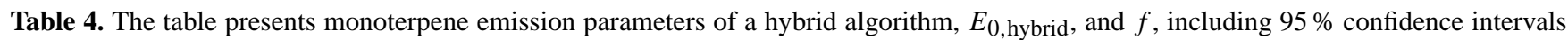
(years 2010-2013). The table shows also correlations coefficients $(r)$, relative errors between the measurements and the calculated values $(\Delta R)$, and a ratio, $\overline{F_{\mathrm{a}}} / \bar{F}$, where $\overline{F_{\mathrm{a}}}$ is an average value of the calculated emissions, and $\bar{F}$ an average value of the measurements. There are also corresponding values of the pool algorithm. If the $p$ value of a correlation was larger than 0.0027 , the result was disregarded as statistically insignificant, and those values are not shown in the table.

\begin{tabular}{|c|c|c|c|c|c|}
\hline Month & $\begin{array}{r}E_{0, \text { hybrid }} \\
{\left[\mathrm{ng} \mathrm{m}^{-2} \mathrm{~s}^{-1}\right]}\end{array}$ & $f_{\text {synth }}$ & $r$ & $\overline{F_{\mathrm{a}}} / \bar{F}$ & $\begin{array}{l}\Delta R \\
{[\%]}\end{array}$ \\
\hline & \multicolumn{2}{|c|}{ Hybrid algorithm } & & & \\
\hline Apr & $280 \pm 50$ & $0.63 \pm 0.12$ & $0.53\left(n=412, p<10^{-4}\right)$ & 0.98 & 64 \\
\hline May & $390 \pm 30$ & $0.70 \pm 0.07$ & $0.72\left(n=512, p<10^{-4}\right)$ & 0.98 & 48 \\
\hline Jun & $320 \pm 25$ & $0.55 \pm 0.11$ & $0.70\left(n=360, p<10^{-4}\right)$ & 0.99 & 48 \\
\hline Jul & $250 \pm 20$ & $0.36 \pm 0.11$ & $0.64\left(n=400, p<10^{-4}\right)$ & 0.99 & 46 \\
\hline Aug & $220 \pm 25$ & $0.39 \pm 0.14$ & $0.52\left(n=400, p<10^{-4}\right)$ & 0.98 & 55 \\
\hline Sep & $290 \pm 70$ & $0.63 \pm 0.16$ & $0.25\left(n=430, p<10^{-4}\right)$ & 0.94 & 81 \\
\hline \multirow[t]{3}{*}{ Oct } & $400 \pm 150$ & $0.79 \pm 0.14$ & $0.38\left(n=102, p<10^{-4}\right)$ & 0.96 & 69 \\
\hline & \multicolumn{2}{|c|}{ Pool algorithm } & & & \\
\hline & $E_{0, \text { pool }}$ & & & & \\
\hline Apr & $145 \pm 15$ & - & $0.48\left(p<10^{-4}\right)$ & 1.05 & 66 \\
\hline May & $220 \pm 15$ & - & $0.65\left(p<10^{-4}\right)$ & 1.07 & 54 \\
\hline Jun & $240 \pm 15$ & - & $0.67\left(p<10^{-4}\right)$ & 1.06 & 51 \\
\hline Jul & $210 \pm 10$ & - & $0.61\left(p<10^{-4}\right)$ & 1.02 & 48 \\
\hline Aug & $170 \pm 10$ & - & $0.48\left(p<10^{-4}\right)$ & 1.01 & 56 \\
\hline Sep & $145 \pm 20$ & - & $0.16(p=0.001)$ & 0.98 & 83 \\
\hline
\end{tabular}

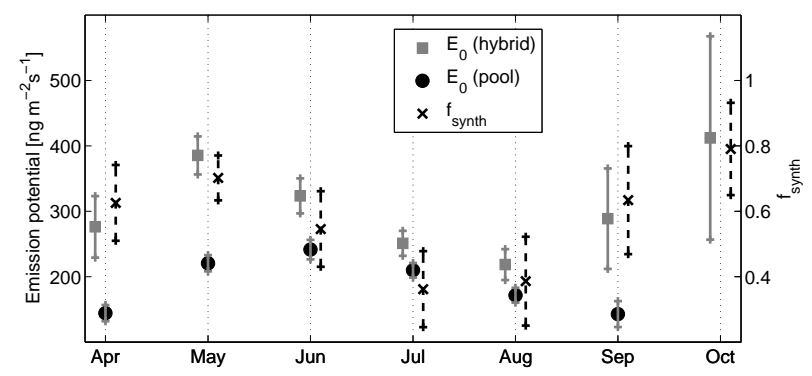

Figure 5. Monoterpene emission potentials of both hybrid algorithm and pool algorithm, and $f_{\text {synth }}$ for each month (years 20102013). Plus signs show $95 \%$ confidence intervals (Table 4).

the direct comparison of the emission potentials between the seasons difficult.

The hybrid algorithm matched with measurements especially well from May until July when $\Delta R<50 \%$ and $r>$ 0.6. Conversely to those months, the measurements from October were noisy leading to somewhat unreliable fitting parameters (Table 4 and Fig. 5). Compared to earlier estimates on autumn monoterpene emissions based on extrapolation of short measurement campaigns (e.g. Rinne et al., 2000a), the autumnal monoterpene emissions were larger than expected. Although one should keep in mind that the data set of this study from October was relatively small, and the results are therefore less representative than from other months. Never-

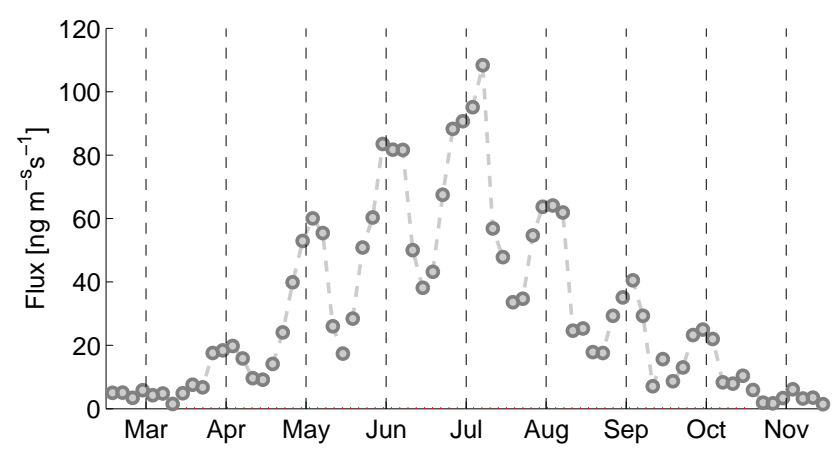

Figure 6. Diurnal cycles (hourly medians) of monoterpene fluxes from March until November (years 2010-2013). The measurements were performed at $0200,0500,0800,1100,1400,1700,2000$, and $2300 \mathrm{UTC}+2$, and the dashed lines represent the noon time.

theless, increased microbiological activity in the autumn has been observed to have an effect on the monoterpene emissions (Aaltonen et al., 2011) which could partly explain the autumn increase in the emission potential. However, the forest floor emissions of monoterpenes determined by Aaltonen et al. (2011) were found to be small, only a few percent, compared with our ecosystem scale results. On the other hand, Hellén et al. (2006) observed much larger forest floor emissions of monoterpenes especially in springtime (up to ca. $\left.100 \mathrm{ng} \mathrm{m}^{-2} \mathrm{~s}^{-1}\right)$. 


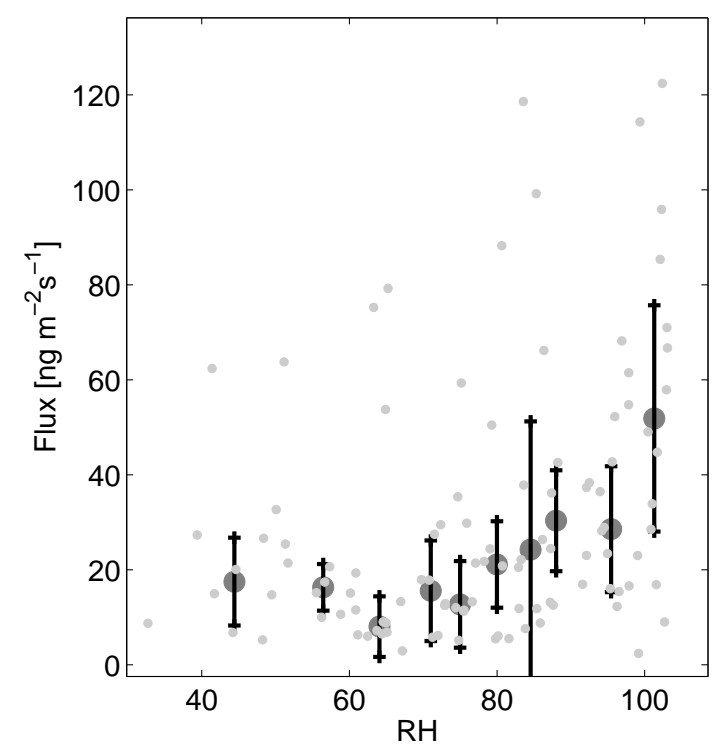

Figure 7. Temperature and PPFD classified $\left(12^{\circ} \mathrm{C} \leq T \leq 15^{\circ} \mathrm{C}\right.$ and PPFD $\leq 50 \mu \mathrm{mol} \mathrm{m}{ }^{-2} \mathrm{~s}^{-1}$ ) monoterpene fluxes (grey circles, bin-medians, $n=15$ ) from May-Aug (years 2010-2013) as a function of relative humidity $(\mathrm{RH})$. Thick black lines represent $95 \%$ confidence intervals of the medians, and grey dots are the measured fluxes.

In addition to the temperature and light intensity, monoterpene emissions have been also connected to other abiotic stresses, such as mechanical damage, high relative humidity, drought, and increased ozone level (e.g. Loreto and Schnitzler, 2009 and references therein). At the ecosystem level, such stress-related emissions could often increase monoterpene fluxes. Thus, they will be incorporated into emission potentials even though the pool algorithm or the hybrid algorithm cannot describe those stress emissions at a process level. We found, for example, a weak dependency between relative humidity and monoterpene fluxes in low (PPFD $<$ $50 \mu \mathrm{mol} \mathrm{m}^{-2} \mathrm{~s}^{-1}$ ) light conditions (Fig. 7). Nevertheless, the measured mean fluxes differed from the predicted mean emissions only a few percent on a monthly basis, i.e. in our data set clear signals of stress-related emissions in a temporal scale of 1 month were not found (see also Fig. 4).

Overall, there were some results that were not totally corresponding with previous monoterpene studies. According to Hakola et al. (2006), monoterpene emissions from two Scots pine branches were highest in June with the (pool) emission potential of ca. $200 \mathrm{ng} \mathrm{m}^{-2} \mathrm{~s}^{-1}$ (calculated using a needle biomass density of $540 \mathrm{~g} \mathrm{~m}^{-2}$ ) whereas the corresponding ecosystem scale emission potential was $240 \mathrm{ng} \mathrm{m}^{-2} \mathrm{~s}^{-1}$ in our study. The numbers are quite close to each other. However, the difference could also mean that ca. $85 \%$ of monoterpene emissions would be originated from Scots pines in June and $15 \%$ from other sources, such as a ground vegetation. The result is realistic as the monoterpene concentrations close to the ground and canopy top are almost equal,
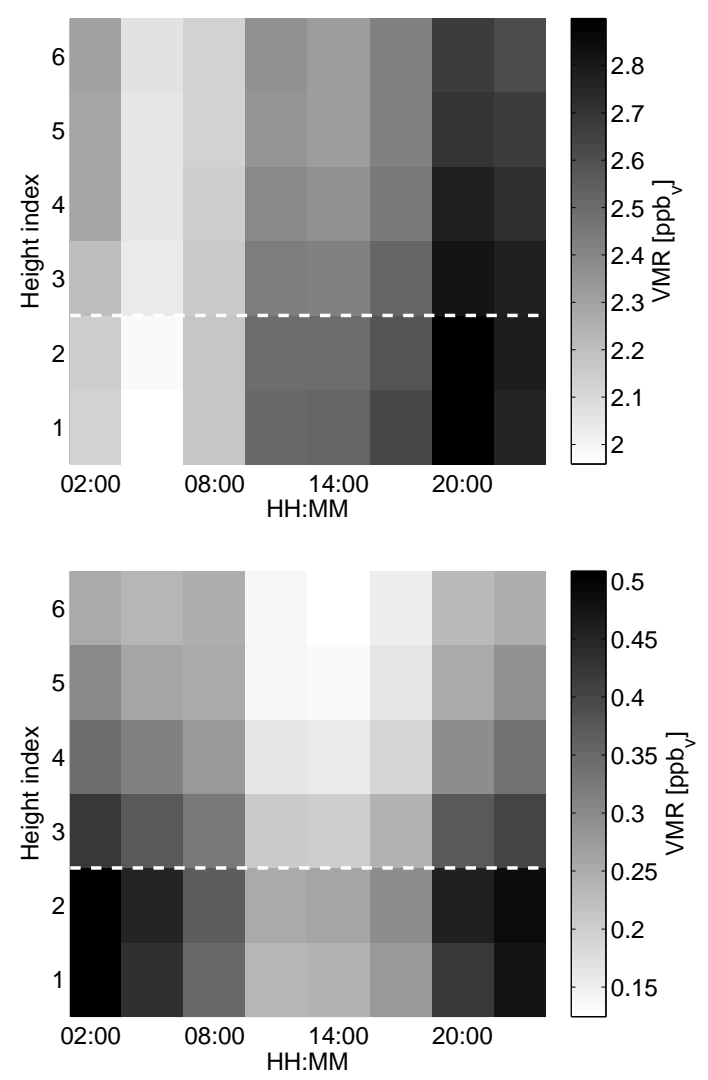

Figure 8. Mean diurnal VMR profiles of methanol (upper panel) and monoterpenes (lower panel, June-August, 2010-2013). Height indexes $1,2,3,4,5$ and 6 correspond to the levels 4.2, 8.4, 16.8, 33.6, 50.4 and $67.2 \mathrm{~m}$, respectively. The white dashed line shows the height of the canopy top.

i.e. monoterpenes should be emitted from the ground as well (Fig. 8). Räisänen et al. (2009) got a similar kind of ratio, $74 \%$, with the ecosystem scale emission potential of $290 \mathrm{ng} \mathrm{m}^{-2} \mathrm{~s}^{-1}$ measured in June-early September. The difference, 85 vs. $74 \%$, is rather small and within uncertainty estimates. On the contrary to June, the emission potential of monoterpenes of September found by Hakola et al. (2006) was only ca. $20 \%$ compared with the corresponding emission potential of this study. This large difference implicates that (i) the emissions of early autumn have large interannual variations, (ii) chamber scale measurements from two branches are unrepresentative or (iii) other sources dominate monoterpene emissions over needles in early autumn.

\subsection{Bi-directional exchange of methanol}

We found periods of net deposition for various OVOCs: methanol, acetaldehyde, acetone and acetic acid. Although for acetic acid, the observed deposition was weak. In the autumn, methanol and acetone fluxes were even dominated by deposition (Table 2). Methanol, acetone and acetaldehyde fluxes had also a negative correlation with the relative 


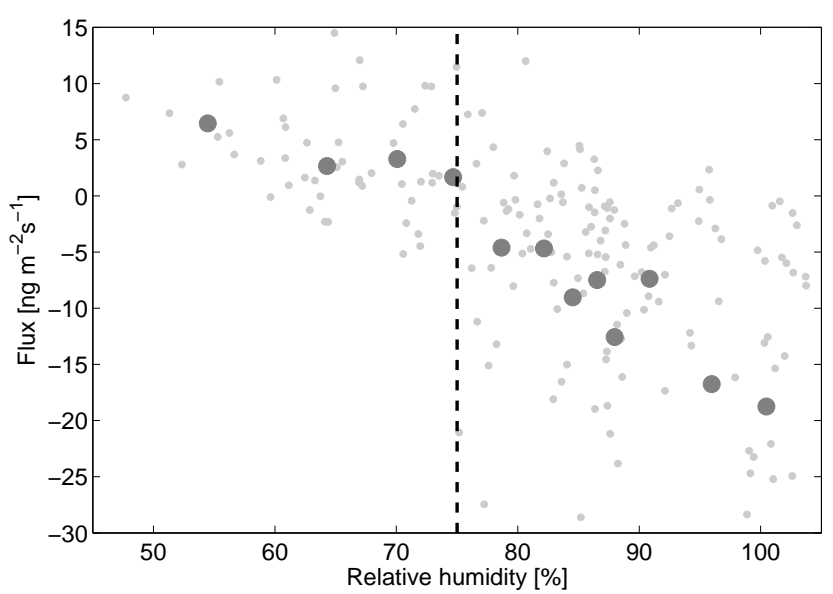

Figure 9. Temperature and PPFD classified $\left(T \leq 15^{\circ} \mathrm{C}\right.$ and PPFD $\leq 50 \mu \mathrm{mol} \mathrm{m}^{-2} \mathrm{~s}^{-1}$ ) methanol fluxes (grey dots) as a function of relative humidity (June-August, years 2010-2013). The grey circles are bin median fluxes $(n=15)$ and the dashed line represents the threshold value $\mathrm{RH}_{0}=75 \%$ (Eq. 14).

humidity (RH) which might indicate the deposition is connected with moisture, such as water films on plant surfaces. However, after normalizing fluxes with the temperature and light, only methanol had a statistically significant relationship with RH (95\% confidence level). Figure 9 shows how both temperature and light classified methanol fluxes behave as a function of relative humidity. The deposition starts at around $\mathrm{RH}=75 \%$, therefore that value was selected as the threshold value $\mathrm{RH}_{0}$ (Eq. 14). Although the method of selecting the threshold value $\mathrm{RH}_{0}$ is somewhat subjective, the value $\mathrm{RH}_{0}=75 \%$ is well in line with earlier observations by Altimir et al. (2006) who found the surface water film starting to occur when $\mathrm{RH}=60-70 \%$. The surface resistance $R_{\mathrm{w}}$ (Eq. 15) was determined by minimizing the relative error between the calculated and measured methanol fluxes in Jul-Aug when the fluxes were the largest. On average, the smallest relative error was obtained with a value of $R_{\mathrm{W}}=120 \mathrm{~s} \mathrm{~m}^{-1}$, thus it was selected to be the constant resistance. Methanol could also deposit to the stomata. However, at least part of the deposition should happen on the non-stomatal surface as the lowest mean concentrations were measured close to the ground during the night-time (Fig. 8).

Measured methanol fluxes were fitted against the exchange algorithm (Eq. 10) for each month. The seasonal behaviour of the emission potentials was found to be similar to monoterpenes: both compounds have the maximum emission potentials in late spring and in autumn, and the lowest emission potential in late summer (Table 5). The high emission potential in May (and June) is probably partly related to growth processes as methanol emissions correlate with leaf growth (e.g. Hüve et al., 2007). The ratio $f_{\text {stomata }}$ (Eq. 11) had a somewhat opposite cycle with the maximum values recorded in summer and the lowest values in spring. This could be related to non-

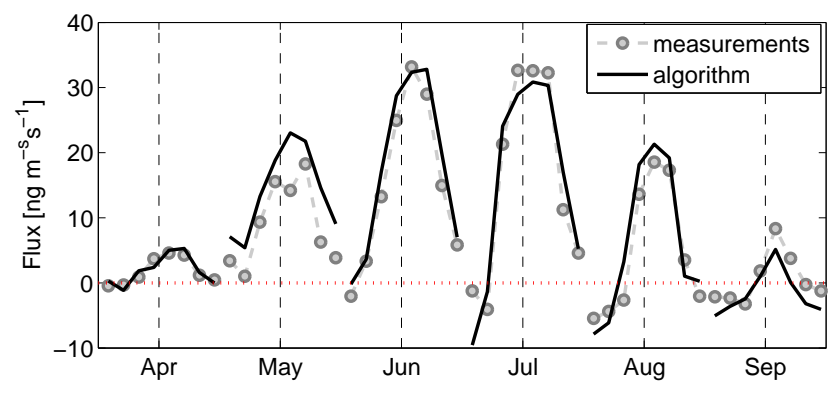

Figure 10. Diurnal cycles (hourly medians) of methanol fluxes from April until October (years 2010-2013). The measurements were performed at 0200, 0500, 0800, 1100, 1400, 1700, 2000, and 2300 $\mathrm{UTC}+2$, and the dashed lines represent noon time.

stomatal emissions in springtime, most probably from decaying litter that is re-exposed after snowmelt. The behaviour is visible in Fig. 3 where normalized methanol emissions are presented as a function of PPFD from each month.

Generally, the algorithm was able to represent the measured values well (Figs. 10 and 4). An exception is May when the measured median daytime values were much lower than calculated values. The relative errors were larger compared with the corresponding results of monoterpenes in every month. This indicates that the measured methanol fluxes were either noisier than measured monoterpene fluxes, or our exchange algorithm could not describe methanol fluxes as well as the hybrid or the pool algorithm describes monoterpene emissions. For example, the parameterization of the RH-filter (Eq. 14) might bring a considerable uncertainty because there may be deposition already at lower relative humidities than $\mathrm{RH}=75 \%$. Moreover, the shape of the $\mathrm{RH}$ response curve $f(\mathrm{RH})$ is probably smoother than a step function (Eq. 14). Nevertheless, the deposition seems to have an important role in a methanol cycle between a surface and the atmosphere. Based on our calculations, the total deposition from April to September was slightly lower than $40 \%$ compared with the total emissions within the same period (Fig. 11). However, it is impossible to distinguish which part of the deposited methanol evaporates back into the atmosphere again. Part of the deposited methanol is removed irreversibly from the atmosphere, as the mean methanol flux is negative in October (Table 2) but the removal processes of methanol from surfaces are generally unknown. Laffineur et al. (2012) estimated that a half lifetime for methanol in water films is $57.4 \mathrm{~h}$ due to chemical degradation but the origin of the process was unidentified. The methanol sink has been also connected to consumption by methylotrophic bacteria (Duine and Frank, 1980; Laffineur et al., 2012).

Rinne et al. (2007) measured methanol fluxes by disjunct eddy covariance method at the same site in July 2007 to have a daytime (10 a.m. -5 p.m.) average of ca. $70 \mathrm{ng} \mathrm{m}^{-2} \mathrm{~s}^{-1}$. These values are twice as high as in this study (Fig. 10) but Rinne et al. (2007) did measurements only during five 
Table 5. The table presents methanol emission potential, $E_{0, \text { meth }}$, including $95 \%$ confidence intervals. The table shows also correlations coefficients $(r)$, relative errors between the measurements and the calculated values $(\Delta R)$, and a ratio, $\overline{F_{\mathrm{a}}} / \bar{F}$, where $\overline{F_{\mathrm{a}}}$ is an average value of the calculated fluxes and $\bar{F}$ an average value of the measured fluxes. $\overline{f(\mathrm{RH}) V_{\mathrm{d}}}$ and $\overline{V_{\mathrm{d}}} \mathrm{RH}>75 \%$ are calculated (Eq. 13) mean deposition velocities (unit $\mathrm{cm} \mathrm{s}^{-1}$ ). If the $p$ value of a correlation was larger than 0.0027 , the result was disregarded as statistically insignificant, and those values are not shown in the table. The really high ratio $\overline{F_{\mathrm{a}}} / \bar{F}$ of September is caused by the fact that the average flux was really close to zero $\left(\overline{F_{\mathrm{a}}} \approx-0.5 \mathrm{ng} \mathrm{m}^{-2} \mathrm{~s}^{-1}\right.$ vs. $\left.\bar{F}=-0.03 \mathrm{ng} \mathrm{m}^{-2} \mathrm{~s}^{-1}\right)$.

\begin{tabular}{lrrcrrrr}
\hline Month & $\begin{array}{r}E_{0, \text { meth }} \\
{\left[\mathrm{ng} \mathrm{m}^{-2} \mathrm{~s}^{-1}\right]}\end{array}$ & $f_{\text {stomata }}$ & $r$ & $\begin{array}{r}\overline{F_{\mathrm{a}}} / \bar{F} \\
{[\%]}\end{array}$ & $\Delta R$ & $\overline{f(\mathrm{RH}) V_{\mathrm{d}}}$ & $\overline{V_{\mathrm{d}} \mathrm{RH}>75 \%}$ \\
\hline Apr & $65 \pm 10$ & $0.45 \pm 0.3$ & $0.39\left(n=449, p<10^{-4}\right)$ & 0.77 & 92 & 0.34 & 0.66 \\
May & $115 \pm 10$ & $0.3 \pm 0.2$ & $0.57\left(n=511, p<10^{-4}\right)$ & 1.09 & 73 & 0.18 & 0.65 \\
Jun & $115 \pm 10$ & $0.65 \pm 0.2$ & $0.59\left(n=365, p<10^{-4}\right)$ & 1.02 & 74 & 0.24 & 0.65 \\
Jul & $75 \pm 5$ & $0.75 \pm 0.15$ & $0.69\left(n=396, p<10^{-4}\right)$ & 0.98 & 63 & 0.19 & 0.64 \\
Aug & $65 \pm 5$ & $0.95 \pm 0.15$ & $0.71\left(n=410, p<10^{-4}\right)$ & 1.05 & 67 & 0.26 & 0.62 \\
Sep & $75 \pm 15$ & $0.6 \pm 0.2$ & $0.48\left(n=307, p<10^{-4}\right)$ & 22 & 88 & 0.50 & 0.64 \\
\hline
\end{tabular}

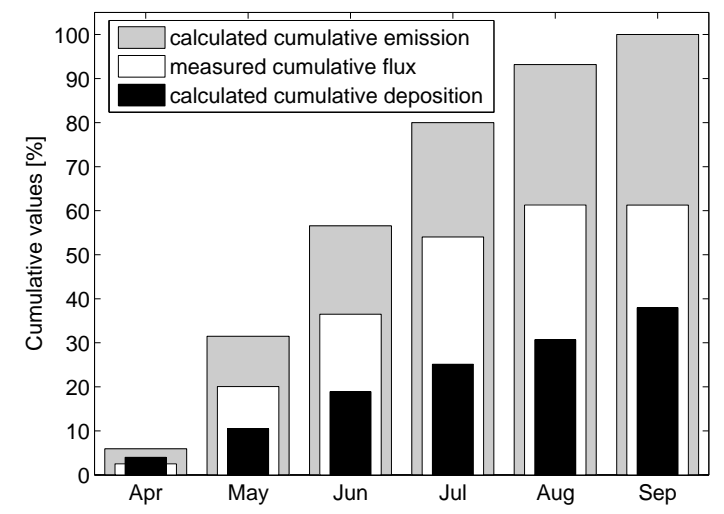

Figure 11. Cumulative methanol emission (calculated), deposition (calculated), and flux (measured) from April until September (years 2010-2013). The values have been scaled so that the maximum cumulative emission in September has the value of $100 \%$. One should note that due to uncertainties in the calculations, substraction between the cumulative emission and the cumulative deposition is unequal to the cumulative flux (Table 5).

quite warm days. The deposition estimates are more difficult to verify as they have been poorly quantified in many studies. In satellite-based methanol inventory by Stavrakou et al. (2011), the deposition velocity of methanol was assumed to increase as function of leaf area index (LAI) to a value of $0.75 \mathrm{~cm} \mathrm{~s}^{-1}$ when $\mathrm{LAI}=6 \mathrm{~m}^{2}$. In addition, Wohlfahrt et al. (2015) concluded that the night-time deposition velocities of methanol are typically in the scale of $<1 \mathrm{~cm} \mathrm{~s}^{-1}$ depending on a plant type. Thus, our results were realistic as the measured mean deposition velocities were between 0.2 $0.6 \mathrm{~cm} \mathrm{~s}^{-1}$ (Table 5). On the contrary, Laffineur et al. (2012) observed very strong methanol deposition with a mean deposition velocity of $2.4 \mathrm{~cm} \mathrm{~s}^{-1}$, although they selected only wet atmospheric conditions for the deposition velocity calculations.

\section{Conclusions}

Using the VOC data set from 4 years, we were able to detect monthly mean fluxes for 13 out of 20 masses (excluding masses heavier than $m / z$ 137) that were statistically different from zero. The largest positive fluxes were those of monoterpenes through almost the whole year, whereas different oxygenated VOCs showed the highest negative fluxes, i.e. deposition. Oxygenated VOCs had also considerable net emission in May and early summer.

The hybrid algorithm described monoterpene fluxes better than the pool algorithm as expected. However, the differences in correlations and relative errors between the pool and the hybrid algorithm were rather small. In the case of the hybrid algorithm, the highest emission potentials of monoterpenes were recorded in May, and on the other hand in October, probably due to different growing and decaying processes. One should still keep in mind that interannual variations of the emission potentials were considerable in May. This indicates that a 1-year data set might be too short for determining representative estimates for emission potentials.

Most of the flux observed at $m / z 69$ was estimated to be isoprene, likely emitted by the nondominant trees and bushes, such as spruce, aspen and willows, in the flux footprint. On the other hand, Scots pine emits also small amounts of MBO, and we detected significant fluxes of $m / z 87$, the unfragmented MBO. Unfortunately, PTR-MS was indirectly calibrated for MBO. Thus, the level of the ecosystem scale MBO fluxes left unknown.

A considerable amount of OVOCs was found to be deposited into the forest, especially in the autumn. We observed that the methanol deposition is probably related to water films on surfaces, which can be parameterized. Deposition mechanisms for other measured OVOCs were left unknown as no significant relationship between the fluxes and the relative humidity or other environmental parameters was found. Nevertheless, mean acetone and also methanol fluxes 
were negative in autumn, which indicates that after depositing, those compounds were not fully re-evaporated back into the atmosphere. Hence, a sink mechanism for some OVOCs should exist. Overall, we estimated that the cumulative deposition of methanol (April-September) is slightly less than $40 \%$ compared with the corresponding cumulative methanol emissions. In reality, the fraction is even larger as methanol has probably net deposition between October and December.

Constructing a simple mechanistic algorithm to describe a methanol exchange between the surface and the atmosphere proved to be challenging. The algorithm constructed here worked well with the tuning parameter values of $\mathrm{RH}_{0}$ and $R_{\mathrm{w}}$ but it is unclear how well those parameters would work at another site. Even though the transferability of this algorithm may depend on the empirical parameters, it can provide a useful tool to analyse the bi-directional methanol exchange. The emission potential of methanol had clear seasonal cycle with the maximum in May/June and the minimum in August, which indicates that the largest emissions originate from growth processes. It was also observed that summertime emissions are strongly light-dependent whereas springtime emissions are more driven by the temperature. One possible explanation is that methanol emissions are controlled by stomatal opening during summer, while in spring time the methanol might be produced partly by decaying litter.

As a final remark, we recommend performing long-term flux measurements for both VOCs and OVOCs above boreal forests. Fluxes of OVOCs, such as methanol and acetone, should be especially studied in more detail in future as the deposition seems to play a significant role in the interaction between the surface and the atmosphere.

Acknowledgements. We acknowledge the support from the Doctoral programme of atmospheric sciences, and from the Academy of Finland through its Centre of Excellence program (Project no 272041). We acknowledge the Academy of Finland (125238) and EU FP7 (ECLAIRE, project no: 282910) for financial support. Technicians and Hyytiälä personnel are also gratefully acknowledged for their help with the measurements. We also thank all people who made the ancillary data available.

Edited by: T. Keenan

\section{References}

Aalto, J., Kolari, P., Hari, P., Kerminen, V.-M., Schiestl-Aalto, P., Aaltonen, H., Levula, J., Siivola, E., Kulmala, M., and Bäck, J.: New foliage growth is a significant, unaccounted source for volatiles in boreal evergreen forests, Biogeosciences, 11, 13311344, doi:10.5194/bg-11-1331-2014, 2014.

Aalto, J., Porcar-Castell, A., Atherton, J., Kolari, P., Pohja, T., Hari, P., Nikinmaa, E., Petäjä, T., and Bäck, J.: Onset of photosynthesis in spring speeds up monoterpene synthesis and leads to emission bursts, Plant Cell Environ., doi:10.1111/pce.12550, 2015.
Aaltonen, H., Pumpanen, J., Pihlatie, M., Hakola, H., Hellén, H., Kulmala, L., Vesala, T., and Bäck, J.: Boreal pine forest floor biogenic volatile organic compound emissions peak in early summer and autumn, Agr. Forest Meteorol., 151, 682-691, 2011.

Aaltonen, H., Aalto, J., Kolari, P., Pihlatie, M., Pumpanen, J., Kulmala, M., Nikinmaa, E., Vesala, T., and Bäck, J.: Continuous VOC flux measurements on boreal forest floor, Plant Soil, 369 , 241-256, 2013.

Altimir, N., Tuovinen, J.-P., Vesala, T., Kulmala, M., and Hari, P.: Measurements of ozone removal by Scots pine shoots: calibration of a stomatal uptake model including the non-stomatal component, Atmos. Environ., 38, 2387-2398, 2004.

Altimir, N., Kolari, P., Tuovinen, J.-P., Vesala, T., Bäck, J., Suni, T., Kulmala, M., and Hari, P.: Foliage surface ozone deposition: a role for surface moisture?, Biogeosciences, 3, 209-228, doi:10.5194/bg-3-209-2006, 2006.

Ambrose, J. L., Haase, K., Russo, R. S., Zhou, Y., White, M. L., Frinak, E. K., Jordan, C., Mayne, H. R., Talbot, R., and Sive, B. C.: A comparison of GC-FID and PTR-MS toluene measurements in ambient air under conditions of enhanced monoterpene loading, Atmos. Meas. Tech., 3, 959-980, doi:10.5194/amt-3959-2010, 2010.

Atkinson, R. and Arey, J.: Gas-phase tropospheric chemistry of biogenic volatile organic compounds: a review, Atmos. Environ., 37, 197-219, 2003.

Bamberger, I., Hörtnagl, L., Walser, M., Hansel, A., and Wohlfahrt, G.: Gap-filling strategies for annual VOC flux data sets, Biogeosciences, 11, 2429-2442, doi:10.5194/bg-11-2429-2014, 2014.

Ciccioli, P., Brancaleoni, E., Frattoni, M., Di Palo, V., Valentini, R., Tirone, G., Seufert, G., Bertin, N., Hansen, U., Csiky, O., Lenz, R., and Sharma, M.: Emission of reactive terpene compounds from orange orchards and their removal by withincanopy processes, J. Geophys. Res.-Atmos., 104, 8077-8094, doi:10.1029/1998JD100026, 1999.

Cussler, E. L.: Diffusion: mass transfer in fluid systems, Cambridge university press, New York, 104-107, 1997.

de Gouw, J. and Warneke, C.: Measurements of volatile organic compounds in the earth's atmosphere using proton-transferreaction mass spectrometry, Mass Spectrom. Rev., 26, 223-257, 2007.

Duine, J. A. and Frank, J.: The prosthetic group of methanol dehydrogenase. Purification and some of its properties, Biochem. J., 187, 221-226, 1980.

Dunne, E., Galbally, I. E., Lawson, S., and Patti, A.: Interference in the PTR-MS measurement of acetonitrile at $\mathrm{m} / \mathrm{z} 42$ in polluted urban air - A study using switchable reagent ion PTR-MS, Int. J. Mass Spectrom., 319-320, 40-47, 2012.

Erickson, M. H., Gueneron, M., and Jobson, B. T.: Measuring long chain alkanes in diesel engine exhaust by thermal desorption PTR-MS, Atmos. Meas. Tech., 7, 225-239, doi:10.5194/amt-7225-2014, 2014

Filella, I., Peñuelas, J., and Seco, R.: Short-chained oxygenated VOC emissions in Pinus halepensis in response to changes in water availability, Acta Physiol. Plant., 31, 311-318, doi:10.1007/s11738-008-0235-6, 2009.

Fuentes, J. D., Wang, D., and Gu, L.: Seasonal Variations in Isoprene Emissions from a Boreal Aspen Forest, J. Appl. Meteorol., 38, 855-869, 1999. 
Ghirardo, A., Koch, K., Taipale, R., Zimmer, I., Schnitzler, J.-P., and Rinne, J.: Determination of de novo and pool emissions of terpenes from four common boreal/alpine trees by ${ }^{13} \mathrm{CO}_{2}$ labelling and PTR-MS analysis, Plant Cell Environ., 33, 781-792, 2010.

Gout, E., Aubert, S., Bligny, R., Rébeillé, F., Nonomura, A. R., Benson, A. A., and Douce, R.: Metabolism of Methanol in Plant Cells. Carbon-13 Nuclear Magnetic Resonance Studies, Plant Physiol., 123, 287-296, doi:10.1104/pp.123.1.287, 2000.

Gray, D. W., Goldstein, A. H., and Lerdau, M. T.: The influence of light environment on photosynthesis and basal methylbutenol emission from Pinus ponderosa, Plant Cell Environ., 28, 14631474, doi:10.1111/j.1365-3040.2005.01382.x, 2005.

Guenther, A. B., Monson, R. K., and Fall, R.: Isoprene and Monoterpene Emission Rate Variability: Observations With Eucalyptus and Emission Rate Algorithm Development, J. Geophys. Res., 96, 10799-10808, 1991.

Guenther, A. B., Zimmerman, P. R., Harley, P. C., Monson, R. K., and Fall, R.: Isoprene and Monoterpene Emission Rate Variability: Model Evaluations and Sensitivity Analyses, J. Geophys. Res., 98, 12609-12617, 1993.

Guenther, A. B., Hewitt, C. N., Erickson, D., Fall, R., Geron, C., Harley, T. G. P., Klinger, L., Lerdau, M., McKay, W. A., Pierce, T., Scholes, B., Tallamraju, R. S. R., Taylor, J., and Zimmerman, P.: A global model of natural volatile organic compound emissions, J. Geophys. Res., 100, 8873-8892, 1995.

Guenther, A., Karl, T., Harley, P., Wiedinmyer, C., Palmer, P. I., and Geron, C.: Estimates of global terrestrial isoprene emissions using MEGAN (Model of Emissions of Gases and Aerosols from Nature), Atmos. Chem. Phys., 6, 3181-3210, doi:10.5194/acp-63181-2006, 2006.

Guenther, A. B., Jiang, X., Heald, C. L., Sakulyanontvittaya, T., Duhl, T., Emmons, L. K., and Wang, X.: The Model of Emissions of Gases and Aerosols from Nature version 2.1 (MEGAN2.1): an extended and updated framework for modeling biogenic emissions, Geosci. Model Dev., 5, 1471-1492, doi:10.5194/gmd-51471-2012, 2012.

Haapanala, S., Rinne, J., Hakola, H., Hellén, H., Laakso, L., Lihavainen, H., Janson, R., O'Dowd, C., and Kulmala, M.: Boundary layer concentrations and landscape scale emissions of volatile organic compounds in early spring, Atmos. Chem. Phys., 7, 1869-1878, doi:10.5194/acp-7-1869-2007, 2007.

Hakola, H., Laurila, T., Lindfors, V., Hellén, H., Gaman, A., and Rinne, J.: Variation of the VOC emission rates of birch species during the growing season, Boreal Environ. Res., 6, 237-249, 2001.

Hakola, H., Tarvainen, V., Bäck, J., Ranta, H., Bonn, B., Rinne, J., and Kulmala, M.: Seasonal variation of mono- and sesquiterpene emission rates of Scots pine, Biogeosciences, 3, 93-101, doi:10.5194/bg-3-93-2006, 2006.

Hari, P. and Kulmala, M.: Station for Measuring EcosystemAtmosphere Relations (SMEAR II), Boreal Environ. Res., 10, 315-322, 2005.

Harley, P., Fridd-Stroud, V., Greenberg, J., Guenther, A., and Vasconcellos, P.: Emission of 2-methyl-3-buten-2-ol by pines: A potentially large natural source of reactive carbon to the atmosphere, J. Geophys. Res.-Atmos., 103, 25479-25486, doi:10.1029/98JD00820, 1998.
Harley, P., Greenberg, J., Niinemets, Ü., and Guenther, A.: Environmental controls over methanol emission from leaves, Biogeosciences, 4, 1083-1099, doi:10.5194/bg-4-1083-2007, 2007.

Heiden, A. C., Kobel, K., Komenda, M., Koppmann, R., Shao, M., and Wildt, J.: Toluene emissions from plants, Geophys. Res. Lett., 26, 1283-1286, doi:10.1029/1999GL900220, 1999.

Hellén, H., Hakola, H., Pystynen, K.-H., Rinne, J., and Haapanala, S.: $\mathrm{C}_{2}-\mathrm{C}_{1} \mathrm{O}$ hydrocarbon emissions from a boreal wetland and forest floor, Biogeosciences, 3, 167-174, doi:10.5194/bg-3-1672006, 2006.

Holzinger, R., Jordan, A., Hansel, A., and Lindinger, W.: Methanol measurements in the lower troposphere near Innsbruck (047 $16^{\prime} \mathrm{N}$; 011 $\left.{ }^{\circ} 24^{\prime} \mathrm{E}\right)$, Austria, Atmos. Environ., 35, 2525 2532, 2001.

Hüve, K., Christ, M., Kleist, E., Uerlings, R., Niinemets, U., Walter, A., and Wildt, J.: Simultaneous growth and emission measurements demonstrate an interactive control of methanol release by leaf expansion and stomata, J. Exp. Bot., 58, 1783-1793, doi:10.1093/jxb/erm038, 2007.

Ilvesniemi, H., Levula, J., Ojansuu, R., Kolari, P., Kulmala, L., Pumpanen, J., Launiainen, S., Vesala, T., and Nikinmaa, E.: Long-term measurements of the carbon balance of a boreal Scots pine dominated forest ecosystem, Boreal Environ. Res., 14, 731753, 2009.

Jacob, D. J., Field, B. D., Li, Q., Blake, D. R., de Gouw, J., Warneke, C., Hansel, A., Wisthaler, A., Singh, H. B., and Guenther, A.: Global budget of methanol: Constraints from atmospheric observations, J. Geophys. Res.-Atmos., 110, D8, doi:10.1029/2004JD005172, 2005.

Kaimal, J. C. and Finnigan, J. J.: Atmospheric Boundary Layer Flows: Their Structure and Measurement, Oxford University press, New York, 11 pp., 1994.

Kajos, M. K., Rantala, P., Hill, M., Hellén, H., Aalto, J., Patokoski, J., Taipale, R., Hoerger, C. C., Reimann, S., Ruuskanen, T. M., Rinne, J., and Petäjä, T.: Ambient measurements of aromatic and oxidized VOCs by PTR-MS and GC-MS: intercomparison between four instruments in a boreal forest in Finland, Atmos. Meas. Tech. Discuss., 8, 3753-3802, doi:10.5194/amtd-8-37532015, 2015.

Karl, T., Harley, P., Emmons, L., Thornton, B., Guenther, A., Basu, C., Turnipseed, A., and Jardine, K.: Efficient atmospheric cleansing of oxidized organic trace gases by vegetation, Science, 330, 816-819, 2010.

Karl, T., Hansel, A., Cappellin, L., Kaser, L., Herdlinger-Blatt, I., and Jud, W.: Selective measurements of isoprene and 2methyl-3-buten-2-ol based on $\mathrm{NO}^{+}$ionization mass spectrometry, Atmos. Chem. Phys., 12, 11877-11884, doi:10.5194/acp12-11877-2012, 2012.

Kazil, J., Stier, P., Zhang, K., Quaas, J., Kinne, S., O’Donnell, D., Rast, S., Esch, M., Ferrachat, S., Lohmann, U., and Feichter, J.: Aerosol nucleation and its role for clouds and Earth's radiative forcing in the aerosol-climate model ECHAM5-HAM, Atmos. Chem. Phys., 10, 10733-10752, doi:10.5194/acp-1010733-2010, 2010.

Kulmala, M., Suni, T., Lehtinen, K. E. J., Dal Maso, M., Boy, M., Reissell, A., Rannik, Ü., Aalto, P., Keronen, P., Hakola, H., Bäck, J., Hoffmann, T., Vesala, T., and Hari, P.: A new feedback mechanism linking forests, aerosols, and climate, Atmos. Chem. Phys., 4, 557-562, doi::10.5194/acp-4-557-2004, 2004. 
Laffineur, Q., Aubinet, M., Schoon, N., Amelynck, C., Müller, J.F., Dewulf, J., Van Langenhove, H., Steppe, K., and Heinesch, B.: Abiotic and biotic control of methanol exchanges in a temperate mixed forest, Atmos. Chem. Phys., 12, 577-590, doi:10.5194/acp-12-577-2012, 2012.

Lindinger, W., Hansel, A., and Jordan, A.: On-line monitoring of volatile organic compounds at pptv levels by means of ProtonTransfer-Reaction Mass Spectrometry (PTR-MS)—Medical applications, food control and environmental research, Int. J. Mass Spectrom., 173, 191-241, 1998.

Loreto, F. and Schnitzler, J.-P.: Abiotic stresses and induced BVOCs, Trends Plant Sci., 15, 154-166, 2009.

Niinemets, U. and Reichstein, M.: Controls on the emission of plant volatiles through stomata: Differential sensitivity of emission rates to stomatal closure explained, J. Geophys. Res.-Atmos., 108, D7, doi:10.1029/2002JD002620, 2003.

Obukhov, A. M.: Turbulence in an atmosphere with a non-uniform temperature, Bound.-Lay. Meteorol., 2, 7-29, 1971.

Oikawa, P. Y., Li, L., Timko, M. P., Mak, J. E., and Lerdau, M. T.: Short term changes in methanol emission and pectin methylesterase activity are not directly affected by light in Lycopersicon esculentum, Biogeosciences, 8, 1023-1030, doi:10.5194/bg-8-1023-2011, 2011.

Paasonen, P., Asmi, A., Petäjä, T., Kajos, M. K., Äijälä, M., Junninen, H., Holst, T., Abbatt, J. P. D., Arneth, A., Birmili, W., van der Gon, H. A. C. D., Hamed, A., Hoffer, A., Laakso, L., Laaksonen, A., Leaitch, W. R., Plass-Dülmer, C., C., P. S., Räisänen, P., Swietlicki, E., Wiedensohler, A., Worsnop, D. R., Kerminen, V.-M., and Kulmala, M.: Warming-induced increase in aerosol number concentration likely to moderate climate change, Nat. Geosci. Lett., 12, 438-442, 2013.

Park, J.-H., Goldstein, A. H., Timkovsky, J., Fares, S., Weber, R., Karlik, J., and Holzinger, R.: Eddy covariance emission and deposition flux measurements using proton transfer reaction - time of flight - mass spectrometry (PTR-TOF-MS): comparison with PTR-MS measured vertical gradients and fluxes, Atmos. Chem. Phys., 13, 1439-1456, doi:10.5194/acp-13-1439-2013, 2013.

Räisänen, T., Ryyppö, A., and Kellomäki, S.: Monoterpene emission of a boreal Scots pine (Pinus sylvestris L.) forest, Agr. Forest Meteorol., 149, 808-819, 2009.

Rantala, P., Taipale, R., Aalto, J., Kajos, M. K., Patokoski, J., Ruuskanen, T. M., and Rinne, J.: Continuous flux measurements of VOCs using PTR-MS - reliability and feasibility of disjunct-eddy-covariance, surface-layer-gradient, and surfacelayer-profile methods, Boreal Environ. Res., 19B, 87-107, 2014.

Rinne, J., Hakola, H., Laurila, T., and Rannik, Ü.: Canopy scale monoterpene emissions of Pinus sylvestris dominated forests, Atmos. Environ., 34, 1099-1107, doi:10.1016/S13522310(99)00335-0, 2000a.

Rinne, J., Tuovinen, J.-P., Laurila, T., Hakola, H., Aurela, M., and Hypén, H.: Measurements of hydrocarbon fluxes by a gradient method above a northern boreal forest, Agr. Forest Meteorol., 102, 25-37, 2000b.

Rinne, J., Taipale, R., Markkanen, T., Ruuskanen, T. M., Hellén, H., Kajos, M. K., Vesala, T., and Kulmala, M.: Hydrocarbon fluxes above a Scots pine forest canopy: measurements and modeling, Atmos. Chem. Phys., 7, 3361-3372, doi::10.5194/acp-7-33612007, 2007.
Rinne, J., Bäck, J., and Hakola, H.: Biogenic volatile organic compound emissions from Eurasian taiga: Current knowledge and future directions, Boreal Environ. Res., 14, 807-826, 2009.

Rinne, J., Markkanen, T., Ruuskanen, T. M., Petäjä, T., Keronen, P., Tang, M.J., Crowley, J. N., Rannik, Ü., and Vesala, T.: Effect of chemical degradation on fluxes of reactive compounds - a study with a stochastic Lagrangian transport model, Atmos. Chem. Phys., 12, 4843-4854, doi:10.5194/acp-12-4843-2012, 2012.

Ruuskanen, T. M., Kolari, P., Bäck, J., Kulmala, M., Rinne, J., Hakola, H., Taipale, R., Raivonen, M., Altimir, N., and Hari, P.: On-line field measurements of monoterpene emissions from Scots pine by proton-transfer-reaction mass spectrometry, Boreal Environ. Res., 10, 553-567, 2005.

Sanhueza, E., Holzinger, R., Kleiss, B., Donoso, L., and Crutzen, P. J.: New insights in the global cycle of acetonitrile: release from theocean and dry deposition in the tropical savanna of Venezuela, Atmos. Chem. Phys., 4, 275-280, doi:10.5194/acp-4-275-2004, 2004.

Schade, G. W. and Custer, T. G.: OVOC emissions from agricultural soil in northern Germany during the 2003 European heat wave, Atmos. Environ., 38, 6105-6114, 2004.

Seco, R., Peñuelas, J., and Filella, I.: Short-chain oxygenated VOCs: Emission and uptake by plants and atmospheric sources, sinks, and concentrations, Atmos. Environ., 41, 2477-2499, 2007.

Sharkey, T. D. and Yeh, S.: Isoprene emission from plants, Annu. Rev. Plant Phys., 52, 407-436, doi:10.1146/annurev.arplant.52.1.407, 2001.

Sindelarova, K., Granier, C., Bouarar, I., Guenther, A., Tilmes, S., Stavrakou, T., Müller, J.-F., Kuhn, U., S tefani, P., and Knorr, W.: Global data set of biogenic VOC emissions calculated by the MEGAN model over the last 30 years, Atmos. Chem. Phys., 14, 9317-9341, doi:10.5194/acp-14-9317-2014, 2014.

Smolander, S., He, Q., Mogensen, D., Zhou, L., Bäck, J., Ruuskanen, T., Noe, S., Guenther, A., Aaltonen, H., Kulmala, M. and Boy, M.: Comparing three vegetation monoterpene emission models to measured gas concentrations with a model of meteorology, air chemistry and chemical transport, Biogeosciences, 11, 5425-5443, doi:10.5194/bg-11-5425-2014, 2014.

Spanke, J., Rannik, Ü., Forkel, R., Nigge, W., and Hoffman, T.: Emission fluxes and atmospheric degradation of monoterpenes above a boreal forest: field measurements and modelling, Tellus, 56, 406-422, 2001.

Spracklen, D. V., Bonn, B., and Carslaw, K. S.: Boreal forests, aerosols and the impacts on clouds and climate, Philos. T. R. Soc. A, 366, 4613-4626, doi:10.1098/rsta.2008.0201, 2008.

Stavrakou, T., Guenther, A., Razavi, A., Clarisse, L., Clerbaux, C., Coheur, P.-F., Hurtmans, D., Karagulian, F., De Mazière, M., Vigouroux, C., Amelynck, C., Schoon, N., Laffineur, Q., Heinesch, B., Aubinet, M., Rinsland, C., and Müller, J.-F.: First space-based derivation of the global atmospheric methanol emission fluxes, Atmos. Chem. Phys., 11, 4873-4898, doi:10.5194/acp-11-4873-2011, 2011.

Taipale, R., Ruuskanen, T. M., Rinne, J., Kajos, M. K., Hakola, H., Pohja, T., and Kulmala, M.: Technical Note: Quantitative long-term measurements of VOC concentrations by PTR-MS measurement, calibration, and volume mixing ratio calculation methods, Atmos. Chem. Phys., 8, 6681-6698, doi:10.5194/acp8-6681-2008, 2008. 
Taipale, R., Kajos, M. K., Patokoski, J., Rantala, P., Ruuskanen, T. M., and Rinne, J.: Role of de novo biosynthesis in ecosystem scale monoterpene emissions from a boreal Scots pine forest, Biogeosciences, 8, 2247-2255, doi:10.5194/bg-8-22472011, 2011.

Tani, A., Hayward, S., and Hewitt, C.: Measurement of monoterpenes and related compounds by proton transfer reaction-mass spectrometry (PTR-MS), Int. J. Mass Spectrom., 223-224, 561578, 2003.

Tarvainen, V., Hakola, H., Hellén, H., Bäck, J., Hari, P., and Kulmala, M.: Temperature and light dependence of the VOC emissions of Scots pine, Atmos. Chem. Phys., 5, 989-998, doi:10.5194/acp-5-989-2005, 2005.

Tie, X., Guenther, A., and Holland, E.: Biogenic methanol and its impacts on tropospheric oxidants, Geophys. Res. Lett., 30, doi:10.1029/2003GL017167, 2003.
Wesely, M. L. and Hicks, B. B.: Some Factors that Affect the Deposition Rates of Sulfur Dioxide and Similar Gases on Vegetation, JAPCA J. Aair Waste Ma., 27, 1111-1116, 1977.

White, M. L., Russo, R. S., Zhou, Y., Ambrose, J. L., Haase, K., Frinak, E. K., Varner, R. K., Wingenter, O. W., Mao, H., Talbot, R., and Sive, B. C.: Are biogenic emissions a significant source of summertime atmospheric toluene in the rural Northeastern United States?, Atmos. Chem. Phys., 9, 81-92, doi:10.5194/acp9-81-2009, 2009.

Wohlfahrt, G., Amelynck, C., Ammann, C., Arneth, A., Bamberger, I., Goldstein, A. H., Gu, L., Guenther, A., Hansel, A., Heinesch, B., Holst, T., Hörtnagl, L., Karl, T., Laffineur, Q., Neftel, A., McKinney, K., Munger, J. W., Pallardy, S. G., Schade, G. W., Seco, R., and Schoon, N.: An ecosystem-scale perspective of the net land methanol flux: synthesis of micrometeorological flux measurements, Atmos. Chem. Phys., 15, 7413-7427, doi:10.5194/acp-15-7413-2015, 2015. 